\title{
Hypotheses to explain the origin of species in Amazonia
}

\author{
Haffer, $J$ * \\ Tommesweg 60, D-45149, Essen, Germany \\ *e-mail: amelie.haffer-penther@t-online.de
}

Received January 29, 2008 - Accepted January 29, 2008 - Distributed November 30, 2008

(With 13 figures)

\begin{abstract}
The main hypotheses proposed to explain barrier formation separating populations and causing the differentiation of species in Amazonia during the course of geological history are based on different factors, as follow: (1) Changes in the distribution of land and sea or in the landscape due to tectonic movements or sea level fluctuations (Paleogeography hypothesis), (2) the barrier effect of Amazonian rivers (River hypothesis), (3) a combination of the barrier effect of broad rivers and vegetational changes in northern and southern Amazonia (River-refuge hypothesis), (4) the isolation of humid rainforest blocks near areas of surface relief in the periphery of Amazonia separated by dry forests, savannas and other intermediate vegetation types during dry climatic periods of the Tertiary and Quaternary (Refuge hypothesis), (5) changes in canopy-density due to climatic reversals (Canopy-density hypothesis) (6) the isolation and speciation of animal populations in small montane habitat pockets around Amazonia due to climatic fluctuations without major vegetational changes (Museum hypothesis), (7) competitive species interactions and local species isolations in peripheral regions of Amazonia due to invasion and counterinvasion during cold/warm periods of the Pleistocene (Disturbance-vicariance hypothesis) and (8) parapatric speciation across steep environmental gradients without separation of the respective populations (Gradient hypothesis). Several of these hypotheses probably are relevant to a different degree for the speciation processes in different faunal groups or during different geological periods. The basic paleogeography model refers mainly to faunal differentiation during the Tertiary and in combination with the Refuge hypothesis. Milankovitch ${ }^{\ddagger}$ cycles leading to global main hypotheses proposed to explain barrier formation separating populations and causing the differentiation of species in Amazonia during the course of geological history are based on different factors, as follow: (1) Changes in the distribution of land and sea or in the landscape due to tectonic movements or sea level fluctuations (Paleogeography hypothesis), (2) the barrier effect of Amazonian rivers (River hypothesis), (3) a combination of the barrier effect of broad rivers and vegetational changes in northern and southern Amazonia (River-refuge hypothesis), (4) the isolation of humid rainforest blocks near areas of surface relief in the periphery of Amazonia separated by dry forests, savannas and other intermediate vegetation types during dry climatic periods of the Tertiary and Quaternary (Refuge hypothesis), (5) changes in canopy-density due to climatic reversals (Canopy-density hypothesis) (6) the isolation and speciation of animal populations in small montane habitat pockets around Amazonia due to climatic fluctuations without major vegetational changes (Museum hypothesis), (7) competitive species interactions and local species isolations in peripheral regions of Amazonia due to invasion and counterinvasion during cold/warm periods of the Pleistocene (Disturbance-vicariance hypothesis) and (8) parapatric speciation across steep environmental gradients without separation of the respective populations (Gradient hypothesis). Several of these hypotheses probably are relevant to a different degree for the speciation processes in different faunal groups or during different geological periods. The basic paleogeography model refers mainly to faunal differentiation during the Tertiary and in combination with the Refuge hypothesis. Milankovitch cycles leading to global climatic-vegetational changes affected the biomes of the world not only during the Pleistocene but also during the Tertiary and earlier geological periods. New geoscientific evidence for the effect of dry climatic periods in Amazonia supports the predictions of the Refuge hypothesis. The disturbance-vicariance hypothesis refers to the presumed effect of cold/warm climatic phases of the Pleistocene only and is of limited general relevance because most extant species originated earlier and probably through paleogeographic changes and the formation of ecological refuges during the Tertiary.
\end{abstract}

Keywords: Amazônia, species origin, paleogeography, river-refuge, speciation.

\footnotetext{
$\uparrow$ The paper was re-printed in its original version. Any alteration in format, not conforming with the present rules of publishing of the Brazilian Journal of Biology is due to this republication.

¥ Milutin Milankovitch (1879-1958), Professor of Theoretical Physics and Celestial Mechanics in Belgrad, analyzed, during the early 1930s, the three pacemakers of global climatic fluctuations during most or all of the geological history of the earth as follow: (1) Precession cycles (ca. 20,000 years) are due to the changing distance earth - sun, (2) obliquity cycles (ca. 40,000 years) to the increasing and decreasing tilt of the equator on earth's orbit around the sun, and (3) eccentricity cycles (ca. 100,000 years) are due to the changing shape of the earth's orbit around the sun.
} 
Haffer, J.

\title{
Hipóteses para explicar a origem das espécies na Amazônia
}

\begin{abstract}
Resumo
As principais hipóteses propostas para explicar as formações de barreiras separando populações e causando diferenciações de espécies na Amazônia são baseadas em diferentes fatores (a maioria históricos), como os seguintes: 1) Mudanças na distribuição da terra e mar ou na paisagem devido a movimentos tectônicos ou flutuações do nível do mar (hipótese Paleogeográfica); 2) o efeito de barreiras dos rios amazônicos (hipótese de Rios); 3) uma combinação de efeitos de barreiras de rios largos e mudanças vegetacionais no norte e sul da Amazônia (hipótese de Refúgio-rios), 4) o isolamento dos blocos de floresta úmida das áreas de relevo de superfície na periferia da Amazônia separadas por florestas secas, savanas e outros tipos de vegetação intermediária durante os períodos climáticos secos do Terciário e Quaternário (hipótese de Refúgios), 5) mudanças na densidade do dossel devido a mudanças climáticas (hipótese de Densidade do dossel), 6) o isolamento e especiação de populações animais em pequenas áreas montanhosas na Amazônia devido a flutuações climáticas sem maiores mudanças vegetacionais (hipótese de Museu), 7) interações competitivas entre espécies e isolamentos de espécies locais em regiões periféricas da Amazônia devido a invasão e contra-invasão durante períodos frios/quentes do Pleistoceno (hipótese Distúrbio-vicariante), e 8) especiação parapátrica através de acentuados gradientes ambientais sem separação das respectivas populações (hipótese de Gradiente). Muitas dessas hipóteses provavelmente são relevantes para diferentes graus de processos de especiação em diferentes grupos da fauna ou durante diferentes períodos geológicos. O modelo básico de paleogeografia refere-se principalmente a diferenciação faunística durante o terciário e em combinação com a hipótese de Refúgio. Os ciclos de Milankovitch que levam a mudanças climáticas-vegetacionais globais afetaram os biomas do mundo não apenas durante o Pleistoceno mas também durante o Terciário e períodos geológicos anteriores. Novas evidências geocientíficas para o efeito dos períodos climáticos secos na Amazônia suportam as predições da hipótese de Refúgios. A hipótese de distúrbio-vicariância refere-se aos presumidos efeitos das fases climáticas frio/quente ocorridos somente no pleistoceno e é de relevância geral limitada, pois a maioria das espécies se originam antes, provavelmente através de trocas paleogeográficas e a formação de refúgios ecológicos durante o Terciário.
\end{abstract}

Palavras-chave: Amazônia, origem das espécies, paleogeografia, teoria dos refúgios, especiações.

\section{Introduction}

The Amazonian rainforest faunas inhabit vast level or hilly plains from the eastern base of the Andes to the Atlantic coast at the mouth of the Amazon River, an immense forested lowland region comprising 6 million sq kilometers. During early stages of the exploration of Amazonia, naturalists already posed the question of the origin of the innumerable species of animals that inhabit these vast rainforests. Most animal species probably originated from populations that developed reproductive isolating mechanisms from their parent species during one or more periods of geographical separation (geographic or allopatric speciation; Mayr, 1942; 1963). Separation of populations may arise (1) from dispersal of a group of individuals of the parent species across a preexisting barrier, e.g. a river, an unsuitable vegetation belt, a mountain range establishing a founder population beyond the barrier (primary disjunction; peripatric speciation) or (2) through a vicariance event fragmenting the continuous range of an ancestral species (secondary disjunction; dichopatric speciation). Whereas jump dispersal is the mode of speciation in animals inhabiting oceanic islands and high mountain tops, most species in lowland regions of the continents probably originated through range fragmentation of ancestral species. The process of speciation is complete when a geographically separated population developed not only reproductive isolation but also ecological separation from the parent species. In this way both became able to coexist in the same area as two different species, when they established secondary contact during later range expansion. Species at intermediate levels of differentiation are also fairly common: these species fail to hybridize but are still incompatible ecologically in areas where they came into contact excluding each other geographically.

The origin of new species within the range of parent species without geographic separation (sympatric speciation) appears likely in certain fruit flies and in the case of some species flocks of freshwater fish found in tiny lakes (Schliewen et al., 1994; Gibbons, 1996; Tregenza and Butlin, 1999). However, it is still unknown whether sympatric speciation occurred more frequently in other groups of animals. My discussions below refer to the history of allopatric speciation in vertebrate animals like amphibians, reptiles, birds and mammals.

Given that most species probably originated allopatrically and that faunal differentiation in Amazonia took place during the entire Cenozoic (Tertiary - Quaternary, i.e. the last 60 million years), the question arises which barriers fragmented the ranges of ancestral species in Amazonia. Historical mechanisms and barriers that have been suggested as effective means of separating populations initiating speciation in this rainforest region include the following (Table 1): (1) the changing distribution of land and sea (Paleogeography hypothesis), (2) the 


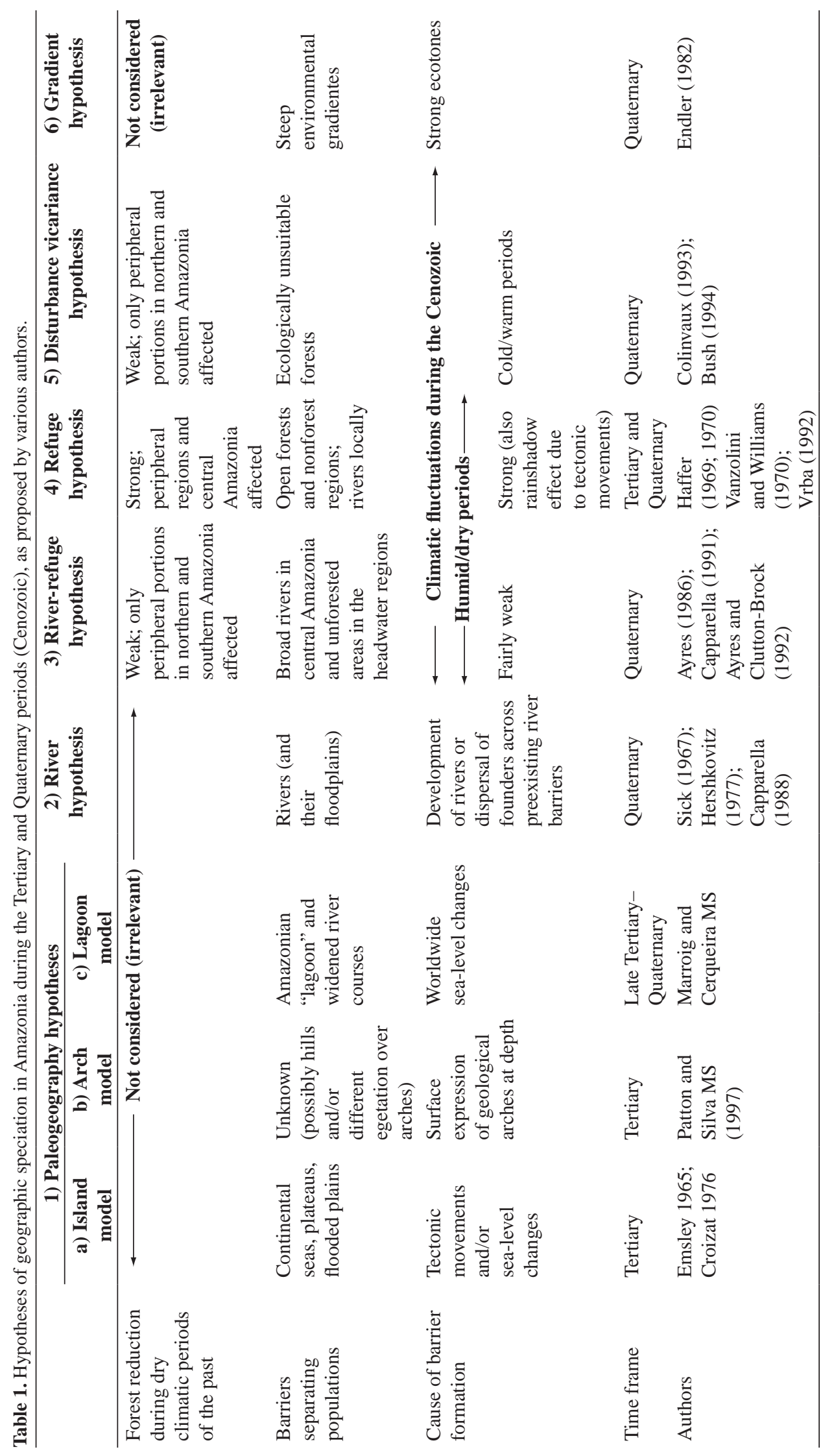


development or presence of river barriers (River theory), (3) a combination of the river effect and of climatic-vegetational changes (River-refuge hypothesis), (4) climatic fluctuations leading to changes in the vegetation cover in portions of Amazonia (Refuge hypothesis), (5) climatic fluctuations leading to speciation in ecologically stable habitat pockets in the mountainous regions surrounding Amazonia without major vegetational changes (Museum hypothesis), (6) cold/warm climatic periods of the Pleistocene presumably leading to changes in the floristic composition of the forests and causing faunal changes and differentiation in peripheral regions of Amazonia (Disturbance-vicariance hypothesis). An additional hypothesis refers to current ecological (rather than historical) factors, i.e. the differentiation across steep ecological gradients due to parapatric speciation (Gradient hypothesis).

I emphasize that these hypotheses have very different relevance as speciation models for Amazonia. Highly relevant are certain paleogeography models and the refuge hypothesis, because they refer to a long geological time span (Tertiary-Quaternary) and to recurrent events of barrier formation. On the other hand, of relatively little relevance are those hypotheses which refer to unique historical events (e.g. the origin of the Amazonian river system) or to a relatively short geological time span (e.g. the disturbance-vicariance hypothesis which refers only to the Pleistocene, i.e. a period after most extant species had originated).

Rigorous testing of these various hypotheses or models is not yet possible in view of the lack of detailed cladistic-systematic data at the species level on one hand and the sparse geoscientific information on the history of Amazonia on the other hand. Below I discuss briefly each of the above mentioned hypotheses and some of their relative merits. In a concluding section I present several distribution maps of forest birds to illustrate several conspicuous patterns of geographical differentiation in this group of Amazonian animals.

Ecological factors that permit the coexistence of species in Amazonia include the following: Small-scale habitat mosaics due to the complex structure of the forest interior, gap phase dynamics, local topography (e.g. hill tops versus intervening valley floors) and fluvial dynamics (vegetation belts along river banks that change their position rapidly). The analysis of these ecological phenomena of local patch dynamics and disturbance cycles of the complex environment as well as of habitat preference of animal species contribute to an understanding in which way the multitude of sympatric species coexist in the same rainforest region. However, in view of the insufficient spatial separation of populations inhabiting these complex habitat mosaics selectively, these ecological factors do not contribute to an understanding of the historical problems of the origin of species in Amazonia. The two distinct and largely independent sets of problems referring, respectively, to the (a) origin and (b) coexist- ence of rainforest species, need to be distinguished in discussions of the "cause" of tropical species richness.

\section{Paleogeography Hypothesis}

The changing distribution of land and sea or changes of certain physical (or ecological) surface conditions are held to have caused the separation and speciation of animal populations in Amazonia under this hypothesis. I distinguish three paleogeographic models, (a) Island model, (b) Arch model and (c) Lagoon model, that are described below.

\subsection{Island model}

Under this model, extant species and subspecies, as well as their distribution patterns, are thought to have originated when populations were repeatedly separated (and later reconnected) on smaller or larger islands isolated from one another by shallow seas due to paleogeographic changes in the distribution of forested land areas and continental seas in tropical South America during the Tertiary (Figure 1a). These changes were caused by fairly gentle (epirogenic) movements, i.e. tectonic uplift or subsidence, over large regions or by more localized (orogenic) mountain building during the last 60 million years (Cenozoic era; Tertiary and Quaternary periods) and before; or these changes were caused by fluctuations of world sea-level leading to repeated flooding (and subsequent falling dry) of low lying areas in Amazonia and on the continental shelves. Under this hypothesis, tectonic movements and the formation of the surface relief in low lying and upland areas of South America (with or without sea-level changes) are considered as necessary and sufficient factors to explain the geographical isolation of populations and resulting speciation (Emsley, 1965; Croizat, 1976).

Occasional marine incursions from the Pacific Ocean and the Caribbean Sea reached western Amazonia during the Tertiary, when this region probably was mostly covered with huge lakes, swamps and river landscapes. This area was closed off from the Pacific Ocean during the Middle Miocene due to the continued uplift of the Andes mountains which eventually led to the reversal of the drainage pattern from the previous western and northwestern direction to an eastern direction. Complete continuity of the Amazon Valley to the Atlantic Ocean developed during the Late Miocene when the northern Andes were strongly uplifted (Katzer, 1903; Nuttall, 1990; Hoorn et al., 1995; Räsänen et al., 1995; Webb, 1995).

It is certain that the Tertiary paleogeographic situation set the stage for evolution of the biota on the Guianan and Brazilian Shields and their surrounding regions. The early proto-Andean islands were gradually united forming long narrow hilly and mountainous ranges during the early Tertiary and were uplifted to present elevation during the course of the late Tertiary and Quaternary. In contrast to the highly dynamic Andean region, the 

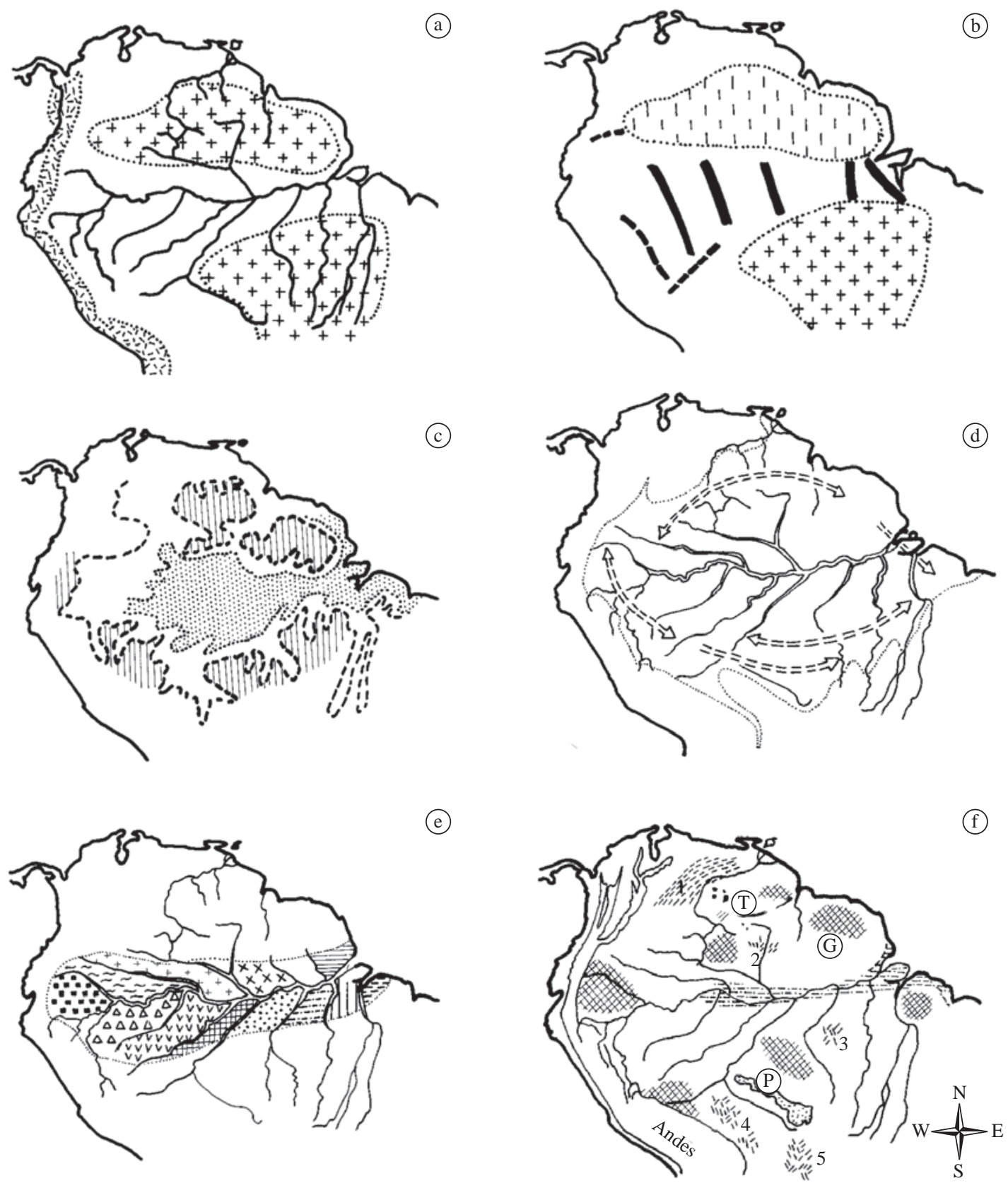

Figure 1. Speciation models proposed for Amazonia (schematic representation). a-c) Paleogeographic hypotheses. a) Island model; crosses indicate Brazilian Shield and Guianan Shield, stipples indicate proto-Andean mountains; number and size of islands vary with assumed height of sea-level; b) Arch model; solid bars indicate central Amazonian arches, dashed bars are tectonic arches in Andean foreland; c) Lagoon model; stippled basin is below $100 \mathrm{~m}$ a.s.l.; hatched areas are above $200 \mathrm{~m}$ a.s.l. d) River hypothesis; open dashed arrows indicate faunal dispersion in headwater regions, where the barrier effect of rivers ceases; stippled line follows outer limit of rainforest; e) River-refuge hypothesis; during dry climatic periods, forest animals are isolated in "semi-refugia" between the broad lower courses of rivers and poorly forested areas in headwater regions (different shading); f) Refuge hypothesis; during dry climatic periods of the Cenozoic, humid rainforests existed adjacent to pronounced relief in peripheral regions of Amazonia (Andes in the west, Tepui mountains $(T)$ and Guiana mountains $(G)$ in the north and Parecís mountains (P) in the south); number and size of refugia remain unknown. Hatched area schematically indicates interglacial embayment (which was not contemporaneous with refuge formation). Regions between humid rain forest refugia presumably were covered with variously extensive dry forest wooded savannas, open liana forests and humid gallery forests. Inactive fossil dunes exist in the Llanos of eastern Colombia and Venezuela (1), in the Rio Aracá - Rio Branco region of northern Brazil (2), in the Beni region of eastern Bolivia (4) and in the Pantanal of western Brazil (5); possibly eolian sands have also been reported from the Cachimbo region in southern Amazonia (3). 
Guianan and Brazilian Shields were fairly stable during the Cenozoic, although they were then gradually uplifted. This uplift to over 2,000 $\mathrm{m}$ in the Tepui mountains of southern Venezuela and in certain portions of the mountains of southeastern Brazil included pronounced local subsidence (e.g. the formation of narrow graben features) as well as extensive dissection of the upland regions and mountain chains. This uplift set the stage for the early evolution of the montane faunas in these regions.

Nores (1999) postulated the flooding of central Amazonia during a late Tertiary period of sea-level rise up to $100 \mathrm{~m}$ above present level. The Venezuelan and Guianan highlands are assumed to have been temporarily separated during this period and several archipelagos are believed to have developed in central Amazonia. This theory is part of the general Tertiary "island model" of faunal differentiation and needs to be considered in conjunction with the effect of other paleogeographical changes in the distribution of land and sea in Amazonia during the Tertiary. Whether or not the many species and subspecies of birds listed by Nores (1.c.) originated at the time of this supposed sea-level rise, had originated earlier or did so later in these regions will depend on further geological and DNA studies. The derivation of the upper Amazonian endemic bird species currently inhabiting the Napo and Inambari regions near the Andes from the assumed small Pliocene archipelagos to the north and south of the upper Solimões River (if they ever existed) appears highly unlikely.

Ron (2000) and Bates (this volume) studied the areas of endemism of different vertebrate groups cladistically using Parsimony Analysis of Endemicity to produce hypotheses of area relationships. The there main clusters are (1) Belém, (2) Guiana and (3) Upper Amazonia (Napo + Inambari) whose origin the related to marine incursions separating these areas during the Tertiary.

Despite occasional marine incursions from the Pacific and the Atlantic Oceans into the Tertiary Amazon basin, the comparatively simple paleogeographic setting of the general Amazon region and the shield areas during that period (of ca. 60 million years duration) does not seem to provide a sufficiently complex and rapidly changing geological theater to have caused the intensive evolution, differentiation and speciation in the lowland faunas that certainly took place there during those times. The paleogeographic setting may have provided no more than the basic framework for evolution to proceed. It appears likely that other factors (in addition to sea-level changes) determined the speciation patterns of the Tertiary faunas in these continental regions such as paleoclimatic fluctuations caused by Milankovitch cycles (see below) leading to frequent ecological vicariance events and the formation of temporary forest and nonforest refugia during the Tertiary (Refuge hypothesis; see below). Ecological refugia may form not only as a result of global climatic fluctuations but also due to fairly local tectonic movements on the shield areas (rain shadow effect).

\subsection{Arch model}

A number of tectonic cross elements (geological 'ridges' or 'arches') connecting the Guianan and Brazilian Shields at depth subdivide the Amazon basin into several geological subbasins (Figure 1b). Under this hypothesis, the arches are assumed to have had some (still unknown) ecological surface expression during the geological past (at least temporarily), like hilly ranges or different vegetation zones compared to the basinal regions between these arches, thereby supposedly separating the ranges of animal species and permitting their differentiation (Patton et al., 2000; Patton and Silva, this volume; Morell, 1996)

The structural arches in the subsurface of the Solimões region (Iquitos arch, Jutaí (Carauarí) arch, Purus arch) originated through tectonic movements during Jurassic time (ca. 150 million years ago). Cretaceous strata of the Alter do Chão Formation overlie unconformably the older (Paleozoic) sedimentary rocks or even the igneous and metamorphic basement as, e.g., over the Iquitos arch (Caputo, 1991). However, the effect of these geologically old arches on the deposition and thickness of the overlying Upper Cretaceous and Tertiary formations has been very slight or negligible. This is indicated by the thickness maps for these formations published by Mosmann et al. (1986) and by the geological cross sections constructed by Caputo (1991): As illustrated on Figure 2, the overall thickness of the Tertiary Solimões Formation increases gradually in upper Amazonia from the Manaus region westward with no effect of the old structural Jutaí and Iquitos arches apparent during the last 60 million years. A slight thinning of the Upper Tertiary Pebas Formation over the former Iquitos arch is schematically illustrated by Petri and Fúlfaro (1983, figure V-5) but appears insufficient to suggest a conspicuous surface expression in this region during the Late Miocene. However, the paleogeographic situation is still poorly known.

Iriondo and Suguio (1981) suggested that vertical movements over the arches have been noticeable into the Holocene, and Mertes et al. (1996) related certain geomorphological features of the present Rio Solimoes floodplain to the continued activity of the structural arches at depth. The river is confined and entrenched in its valley, is relatively straight and is relatively immobile, where it crosses the surface projection of the pre-Cretaceous arches. The valley widens gradually and the Solimões River meanders strongly in the basinal regions between the arches. If these geomorphological features of the Rio Solimões Valley are indeed causally related to subtle tectonic activity of the old arches at depth, their surface expression during the Tertiary and Quaternary presumably has never been more conspicuous than at the present time. They hardly caused the formation of ecological or physical "barriers" at the surface effectively separating animal populations on either side, as suggested by Patton et al. (2000) and Patton and da Silva (this volume). The "Arch model" appears to be 

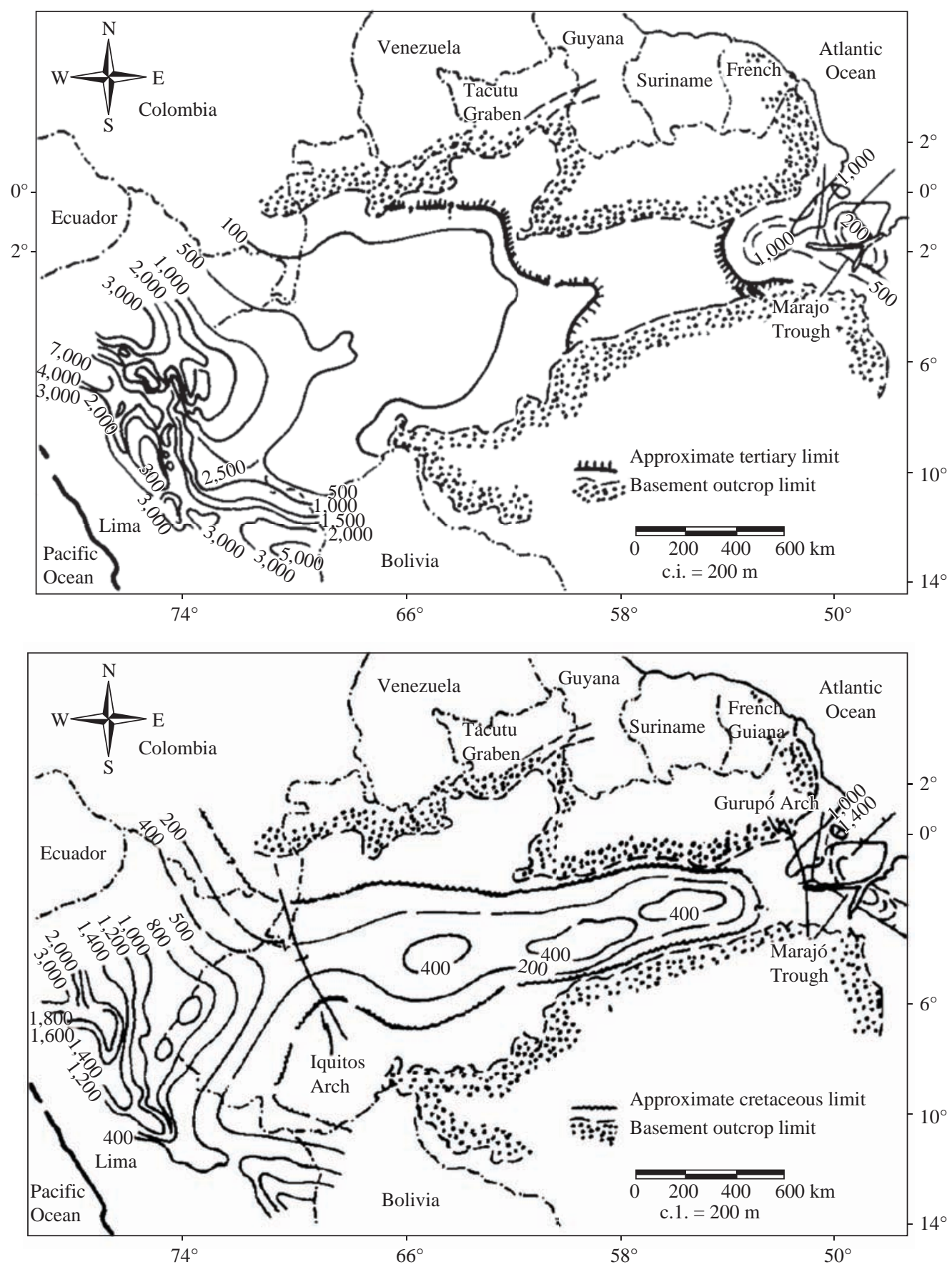

Figure 2. Thickness maps of the Tertiary Solimoes Formation (above) and the Cretaceous Alter do Chao Formation (below) in Amazonia. Notice the drainage divide in central Amazonia (below Manaus) during the Tertiary and the Iquitos arch separating the Amazon basin from the sub-Andean Peruvian-Acre basin during the Cretaceous; this arch apparently was inactive during the Tertiary (Mosmann et al., 1986).

flawed on geological grounds and is highly speculative. Moreover, the position of the phylogeographic breaks of extant mammals along the Rio Juruá in western Brazil that formed the basis for this model (Patton and da Silva, 1994), approximately coincides with the border between the geomorphological "Rio Acre-Rio Javarí depression" and the "Planalto Rebaixado da Amazonia" (Projeto RadamBRASIL, 1976; 1977). Thus, the break analyzed by the above authors may be related to the present ecological surface configuration and corresponding vegeta- 
tion zones rather than to the geological arches in the subsurface. Alternatively, the phylogeographic breaks may represent zones of secondary contact between populations that reestablished contact when, after a dry climatic period, dense forests returned to the Juruá region, as suggested by fossil mammals that inhabited a savanna-forest mosaic in this region during dry climatic periods of the Pleistocene (see below).

In contrast to the geologically old arches in the subsurface of the Solimões region, other younger structural arches in the Andean foreland originated in conjunction with the uplift of the mountains and still today represent gentle morphological surface features (Vaupés arch, Fitzcarrald arch, Serra do Moa arch; Räsänen et al., 1990; 1992). Animal species inhabiting the forests over these arches may have been partially isolated when the intervening basinal regions were flooded during humid climatic periods of the past.

A portion of the present lower Amazon Valley, i.e. the region between Manaus and Obidos, was apparently land during long periods of the Tertiary, when this area permitted a direct faunal exchange between the land regions of the Guianan Shield to the north and the Brazilian Shield to the south (Figure 2). Until the late Miocene, this "bridge" was a gentle divide between the broad upper Amazonian (Solimoes) basin to the west and the comparatively small sedimentary basin under the lowermost Amazon Valley including the Marajó trough to the east (Mosmann et al., 1986). This low drainage divide disappeared during the late Miocene tectonic movements leading to the continuity of the Amazon Valley from the upper Solimões region to the Atlantic Ocean.

\subsection{Lagoon model or lake model}

This hypothesis is based on the assumption that most of Amazonia was covered by a huge lake or lagoon at the end of the Tertiary (Pliocene), and successively smaller portions of Amazonia were covered during a series of assumed high sea-level stands during the Quaternary (e.g. $+70,+55,+31,+22,+9 \mathrm{~m}$ above present sea-level) supposedly documented by corresponding terrace levels in the lower Amazon Valley (Sombroek, 1966; Klammer, 1984). The proponents of this model (Marroig and Cerqueira, 1997) assume that the flooding of the Amazon basin to $+180 \mathrm{~m}$ (and lower levels) pushed the rainforests to peripheral regions of the Amazon basin where, in addition, the broadened rivers separated populations of ancestral animals on forest "islands" (Figure 1c).

This speciation model is highly flawed for the following reasons: (1) The Belterra clays covering the $180 \mathrm{~m}$ terraces in lower Amazonia and previously interpreted as the deposits of a Pliocene "Belterra Lagoon" are apparently nothing but the product of tropical weathering of the underlying bedrock, i.e. residual clays (Irion, 1984a;b). Thus the Belterra clays have no paleogeographic significance whatsoever. (2) Moreover, the nine terrace levels of the lower Amazon Valley (including the $180 \mathrm{~m}$ level) probably have a tectonic origin and are not due to high sealevel stands. They may be related to pulses of uplift and deposition of coarse debris from the shield areas during climatic fluctuations of the Quaternary (Clapperton, 1993:59). Therefore these terraces cannot be used as evidence for partial flooding of Amazonia. Global sea-level probably never rose much more than 4-6 $\mathrm{m}$ above its modern level during the Quaternary. The Mediterranean high shorelines of the Quaternary are also due to tectonic uplift (Clapperton, 1993). Because of these reasons the Lagoon model is untenable.

A variant of the Lagoon model envisions flooding of large parts of Amazonia to even more than $200 \mathrm{~m}$ above present sealevel ("Lake Amazonas"), when an Andean paleolake drained catastrophically 45,000 to 40,000 years ago (Frailey et al., 1988, Campbell, 1990). These authors assumed a dam near the mouth of the Amazon River supposedly consisting of Belterra clay that prevented the floodwaters from rapidly emptying into the Atlantic Ocean. The biogeographical implications of this vast lake, if it existed, would be that portions of the forest fauna survived the flood in relatively small disjunct pockets of rainforest located along the irregular margins of "Lake Amazonas". Tuomisto et al. (1993) critically reviewed this hypothesis concluding that it was not supported by geological field data. Räsänen et al. (1995) attributed at least part of the postulated lacustrine strata to the Miocene and Clapperton (1993) felt that this "megaflood" hypothesis should not be taken seriously. Two age dates for upper Cenozoic volcanic ash deposits from easternmost Peru have become available (9 and 3 million years before present) and stablish approximate time constraints for the last major cycle of Cenozoic deposition in southwestern Amazonia (Campbell et al., 2001).

\section{River Hypothesis or Riverine Barrier Hypothesis}

Amazonian rivers are thought to have acted as barriers separating populations and permitting their differentiation to the levels of subspecies and species. Three variants of this hypothesis may be distinguished: (a) origin of the river system, (b) later adjustments of the location of river courses, and (c) dispersal of founders across a river barrier. Under the first model, widespread and uniform ancestral populations of Amazonian animals are assumed to have been divided into subpopulations and effectively isolated, when the network of wide Amazonian rivers developed during the late Tertiary and early Quaternary (Figure 2d). As Sick (1967: 501) stated, numerous ancestral Amazonian species supposedly had a vast and more or less uninterrupted distribution in a continuous forest region that was not (yet) traversed by large rivers. When these developed, many populations, especially those inhabiting the forest interior, became effectively separated and deviated to the level of subspecies and species on opposite river banks (or on opposite sides of the flood plains). Capparella (1988) similarly 
suggested that the development of the river system in Amazonia dissected once-continuous lowland forest, leading to population fragmentation and high diversity of avian species, especially in birds of the forest understory. This basic River model of speciation appears to be flawed, because the development of the great forest and of its large rivers was probably one interrelated process. The forest cannot be envisioned without wide rivers and vice versa. The other two variants of the River hypothesis either refer to shifts of the location of rivers in a preexisting fluvial system or assume the active or passive dispersal of founders (individuals or groups of individuals) across river barriers at any time after the formation of the rivers, interpreting the disjunction of populations as primary rather than secondary.

The River hypothesis in one or the other variant form has been invoked on many occasions to explain certain situations, but has never been discussed in any detail or tested on the basis of the distribution patterns of a large faunal group over the entire Amazon region. Field naturalists observed since the mid $19^{\text {th }}$ century that the Amazon River and some of its tributaries separate, at least for some distance, the ranges of many forest interior species and subspecies of animals (Wallace, 1852; 1853; Bates, 1863 [for various groups of animals], Hellmayr, 1910; 1912; Snethlage, 1913; Mayr, 1942: 228; Sick, 1967 [for birds]; Hershkovitz, 1977; Ayres, 1986; Ayres and Clutton-Brock, 1992 [for primates]).

There is no question that the broad lower portions of many Amazonian rivers, often in conjunction with their much wider floodplains, effectively separate populations of many forest animals, thus causing the development or enhancement of genetic differences of the separated though still conspecific populations. This has been demonstrated by Capparella (1988) on the basis of his study of allozymic differences among river-separated forest bird populations. However, these genetic differences possibly disappear gradually toward the headwater region of the respective rivers where the latter cease to be effective barriers and more or less uninhibited gene flow connects the broadly intergrading populations which, on the other hand, are indeed effectively separated by the wide lower stretches of the same rivers and their floodplains (Figure 1d). Alternatively, when a wide river valley separates two closely related taxa, these often are in direct contact in the headwater region, where one of them crossed the narrower river course resulting in a variously extensive overlap zone ("good" species), a hybrid zone (subspecies) or in geographical exclusion of their ranges along an abrupt parapatric contact zone without hybridization (paraspecies). Such contact zones (indicating lack of geographical separation) prevent the direct application of the River hypothesis in these cases. The question is still unsolved whether the barrier effect of Amazonian rivers during the geological past has often been sufficiently effective to have caused species differentiation to occur in animals, or whether this isolation effect in many or most cases was rather localized, leading to the development of intraspecific differences of certain populations on opposite sides of the lower stretches of Amazonian river valleys, initiating the process of speciation in these cases.

Many authors invoking the River hypothesis of speciation overlooked and left undiscussed the problems associated with the lack of spatial separation of populations in the headwater regions. The question is not whether wide rivers are barriers to gene flow for understory birds or whether genetic differences have evolved in populations separated by wide river courses in central Amazonia. This appears obvious (as in many populations separated by other kinds of barriers on continents). Rather, the question is whether the barrier effect of rivers in Amazonia has been sufficiently effective to have led routinely to full speciation in understory birds and other animal groups (despite the lack of isolation in the headwater regions of the rivers).

I list below a number of difficulties with the River hypothesis that are usually not considered by authors favoring this hypothesis:

1) The frequent transfer of an extensive portion of land to the opposite side of a river each time a meander loop is cut off or a new river course carved out within the floodplain. In this way, even poorly dispersing animals of the floodplains are routinely "transported" passively across most small rivers and even large streams such as the the Rio Solimoes and the Amazon rivers.

2) The lack of geographical separation of populations in the forested headwater regions where the rivers cease to be barriers (as noted already by Wallace [1852:110]: "On approaching the sources of the rivers they cease to be a boundary, and most of the species are found on both sides of them.")

3) A number of representative taxa of the forest interior whose ranges are separated by rivers occupy (as uniform and phenotypically undifferentiated populations) extensive areas which are traversed by larger rivers than those that separate the ranges of these representatives. Future analyses will demonstrate whether or not such river-separated and uniform populations exhibit strong genetic differences.

4) The occurrence of numerous secondary contact zones between Amazonian subspecies and species of birds and other animals in continuous terra firme forest regions (their locations, in many cases, being unrelated to large rivers which these contact zones cross at right angles; see below).

5) The conspicuously reduced barrier effect of large rivers during periods of lowered sea-level of the Pleistocene (by up to $130 \mathrm{~m}$ ), when these rivers were narrower than today, flowing in more deeply incised "canyons."

6) Genetic population studies of rats (Silva and Patton, 1993; Patton et al., 1994; Patton et al., 2000), frogs (Gascon et al., 1998) and Saddle-back Tamarins 
(Peres et al., 1996; Patton et al., 2000) from the Rio Juruá region in southwestern Amazonia do not support the river hypothesis of speciation but are more consistent with an interpretation of populations having established secondary contact in this region.

The problem of speciation in birds inhabiting rivercreated vegetation zones and in strong-flying canopy birds and other animals that readily cross broad rivers is left unexplained by the River hypothesis whose application many authors restricted to birds of the forest understory. Fjeldsa (1994: 217) dismissed the River theory concluding that "probably most of the differentiation happened by isolation in habitat pockets along the Amazon basin periphery. As the species later dispersed, the rivers became natural 'sutures' between some of the sister taxa".

I do not mean to say that Amazonian rivers were unimportant, but they appear to have been overrated as barriers to the dispersal of sedentary animals. The broad lower courses of only a few large rivers represent effective barriers to a portion of the vertebrate fauna, especially species of the forest interior (many of which, however, surround the river barriers in the headwater regions). Generally speaking, the numbers of species whose ranges are delimited by rivers increase with the width of Amazonian rivers. The broad Amazon River itself, of course, is a strong barrier. Among a sample of 360 forest bird species, the upper Amazon (Rio Maranón) delimits the ranges of fewer than 20 species (Figure 3; Haffer, 1978 ; 1992). Going downstream this number increases along the middle Amazon (Rio Solimoes) to more than 50 species and reaches a total of over 150 species along the lower Amazon River below the mouth of the Rio Negro. The barrier effect decreases again near its mouth where large islands like Marajó, Mexiana and others facilitated increased avifaunal exchange from north to south (and vice versa) and was probably further enhanced by the repeated glacial lowering of world sealevel, when large areas of the continental shelves fell dry. The broad lower courses of the Amazonian tributary streams Rio Negro, Rio Madeira, Rio Tapajós and Rio Tocantins delimit the ranges of 20 to 70 species in the above sample. The study of Ayres (1986) and Ayres and Clutton-Brock (1992) demonstrated that the barrier effect of Amazonian rivers for primates is comparable to that for birds. The decrease of the barrier effect of the Amazon River going upstream toward the Rio Maranón is conspicuous. On the other hand, the barrier effect for primates sharply increases below the mouth of the Rio Negro but decreases again near the mouth of the Amazon.

\section{River-Refuge Hypothesis}

The model that I designated River-refuge hypothesis (Haffer, 1992; 1993) combines aspects of the River hypothesis and of the Refuge hypothesis of faunal differentiation. Animal populations have been presumably

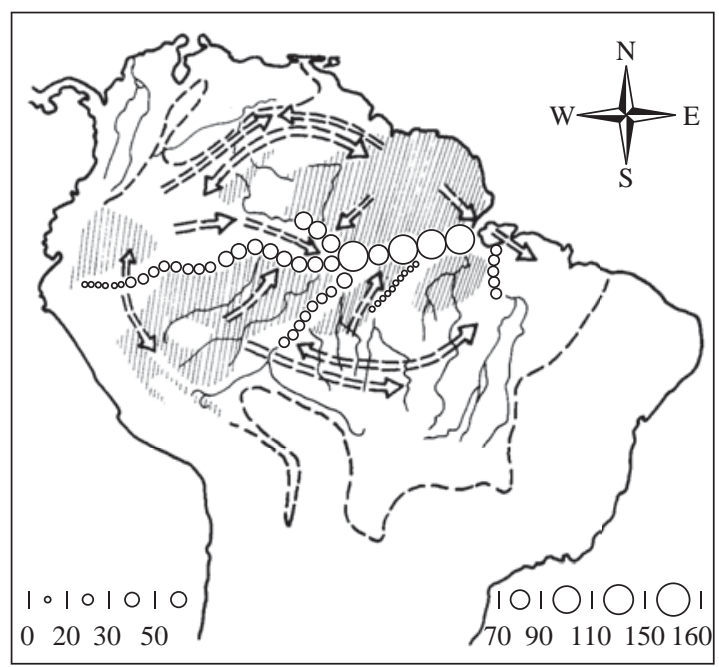

Figure 3. Barrier effect of broad river valleys for birds in Amazonia (open circles) and main avian dispersion routes (Open circles illustrate) in interfluvial regions and in the headwater areas of major rivers, where the latter cease to act as barriers. Solid circles illustrate varying numbers of species range borders along the Solimoes-Amazon River and along the lower portions of its major tributaries (see scale). Data derived from sample of 360 species maps. Shadded areas have less than 10 species range borders per $100 \mathrm{~km}$ distance. The increasingly crowded contour lines near the northern and southern limits of the Amazonian-Guianan forest region are not shown. Dashed line follows zero contour of total sample. Insufficient data are available to estimate the (somewhat reduced) barrier effect of the Amazon River near its mouth (Marajó Island). Modified from Haffer (1978).

isolated in "semi-refugia" separated by a combination of the broad lower courses of several Amazonian rivers (plus their floodplains) and by extensive, ecologically unsuitable terrain in the headwater regions of northern and southern Amazonia that were more or less unforested during dry climatic periods when the zone of tropical forests supposedly contracted toward the equator on broad latitudinal fronts (Ayres, 1986; Ayres and Clutton-Brock, 1992; Capparella, 1991). This hypothesis (Figure 1e) should not be included under the same designation as the River hypothesis, because the effect of repeated climatic-vegetational changes is not required under the latter hypothesis, whereas the effect of such changes is an essential part of the River-refuge model (and of the Refuge hypothesis; see below). The Amazon forest region contracted in a north-south direction under the River-refuge model but did not fragment. Therefore, the designation "River-forest contraction hypothesis" would also be feasible for this model. However, I prefer the label "River-refuge hypothesis", because this model is somewhat intermediate between the River model and the Refuge model and draws arguments from both. The River-refuge hypothesis was proposed on the basis of the 
patterns of distribution of Amazonian primates (Ayres, 1986; Ayres and Clutton-Brock, 1992) and a study of certain bird species of the rainforest understory (Capparella, 1991).

Assuming, as a first approximation, a more or less uniform reduction of humidity and rainfall over Amazonia during dry climatic periods, this would probably lead not only to a contraction of the Amazon forest from the north and south, but would also cause the separation of upper Amazonian forest blocks from lower Amazonian forest blocks along the conspicuous dry transverse belts that cross southwestern and central Amazonia from southeast to northwest (Figure 4; Van der Hammen and Absy, 1994; Van der Hammen, this volume). Geological data from Pitinga, north of Manaus, and from the Tapajós region (see below) appear to corroborate this assumption thus favoring the Refuge model over the River-refuge model.

\section{Refuge Hypothesis}

The Refuge model holds that species originated due to climatic-vegetational changes leading to the separa- tion of animal and plant populations in "refugia" and their later range expansion under the varying cool/dry to warm/humid climatic conditions of the Cenozoic (Tertiary and Quaternary periods) and before (Haffer, 1969; 1982; 1993; Vanzolini, 1970; 1973; 1992; Müller, 1973; Prance, 1973; Brown et al., 1974, Hooghiemstra and van der Hammen, 1998); see Figure 1f. There have been closed vegetation formations (forests), intermediate and open formations during dry climatic periods, although the species composition of forest and nonforest biomes differed from today. Communities disrupted, plant and animal species changed their distributions individualistically during these climatic fluctuations at 20 to 100 thousand year time-scales (Milankovitch cycles). The number and size of refuges during the peaks of the various dry (not arid) climatic periods and the type of vegetation separating the rainforest refuges (dry forest, open forest, savanna vegetation) remain unknown. It is postulated that there have been many different periods of the formation of forest refugia and nonforest refugia on land areas due to the effects of Milankovitch cycles over the last 60 million years and before. Plant and animal populations confined to the more or less isolated forest

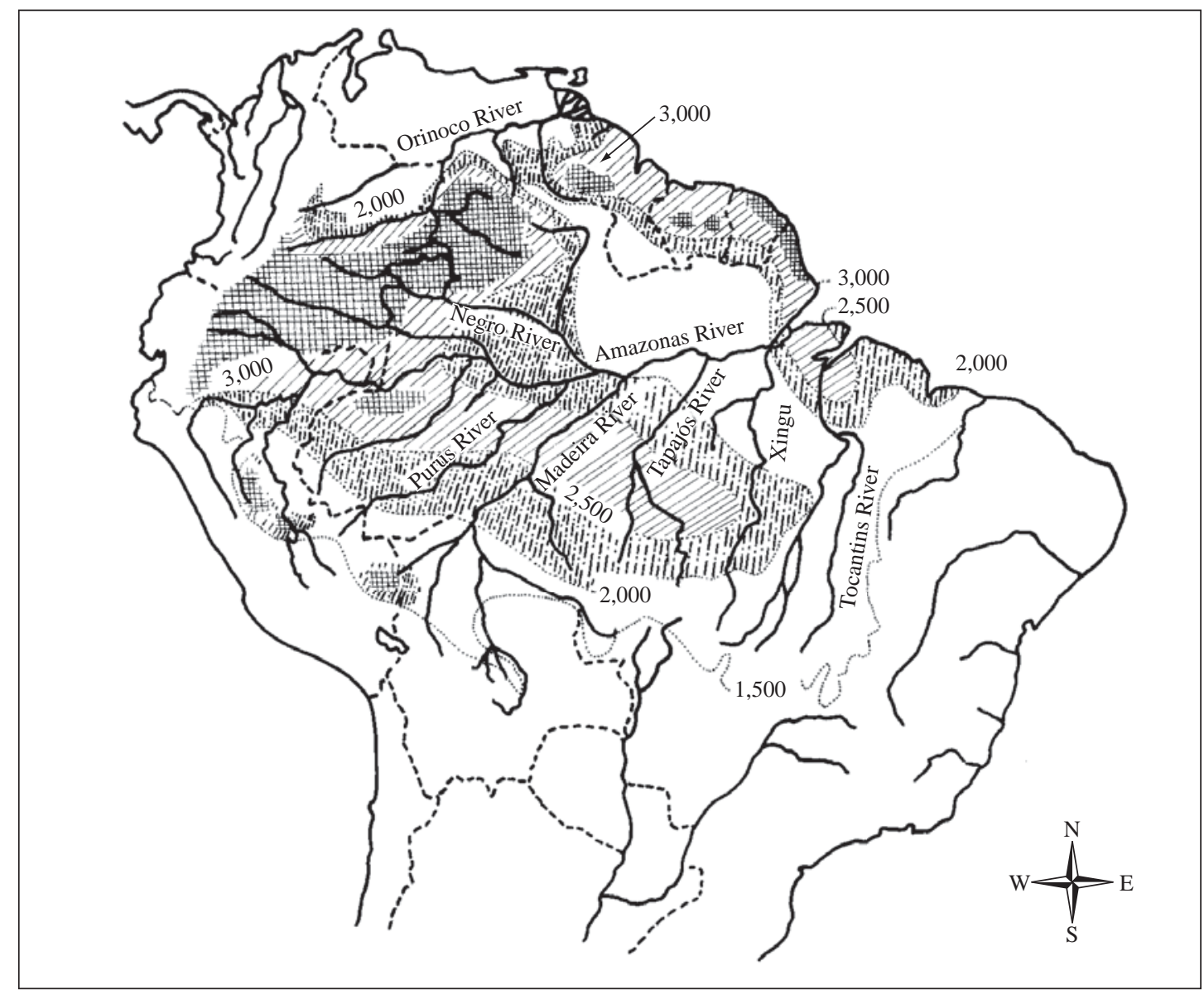

Figure 4. Annual rainfall (mm) in Amazonia and names of major rivers. Areas near base of the Andes receive more than $4000 \mathrm{~mm}$ of rain per year. Compiled from several sources. 
refugia of varying size either became extinct, survived without much change or differentiated to the taxonomic levels of subspecies or species before the unaltered survivors and the newly differentiated taxa came into secondary contact with their representative populations of other refugia during a following favorable expansive phase. If at this time a refuge population had reached sexual and ecological isolation from its neighboring allies, it could disperse widely in the now-continuous habitat before its extensive range was fragmented again during the next adverse climatic phase. Some species remained more or less restricted to the areas of their origin without expanding their ranges widely in the continuous forest region (in this way characterizing today a number of "areas of endemism"). It remains unknown whether extinction of species or generation of species was prevalent during particular periods of refuge formation, leading to a reduction or increase of overall regional species diversity, respectively. Newly differentiated species probably survived many periods of environmental change before they speciated again.

In summary, Refuge hypothesis refers to recurrent paleoecological changes on tropical land areas over a long geological time span. Specifically, it suggests that (a) ecological conditions were not stable in tropical latitudes during the Cenozoic, alternating humid and dry climatic periods leading to continuous vegetational changes, (b) allopatric speciation and subspeciation of forest and nonforest faunas took place during adverse climatic periods in isolated populations, and (c) particular regions acted as areas of differentiation ("refugia"). Originally applied to the tropical regions during the Quaternary only, the theory has been extended to the Tertiary with the realization of a strong effect of Milankovitch cycles on the biomes of the world during the entire Cenozoic and before. It is likely that the climatic forcing at 20 to 100 thousand year time-scales has been a factor in pacing climatic change throughout Earth history. Disruption of communities due to the effect of Milankovitch cycles has been a permanent feature at 20 to 100 thousand year time-scales, although usually unrecognized because of the relatively coarse resolution of most of the paleontological record (Bennett, 1997: 185). The general aspects of the refuge hypothesis challenged the earlier view that the tropics were unaffected by climatic fluctuations of the Cenozoic, the biota supposedly having differentiated exclusively due to paleogeographical changes during the Tertiary. As Morley (2000: XIII) emphasized, the "immense diversity [of the tropical rainforests] is due not to a long, unchanging history, with stable climatic conditions over millions of years, but to the ability of opportunistic plants to survive through periods of climatic change and geological upheaval, to expand their distributions, when changing climates permit, [and] to retreat to favorable refuges when climates were unfavourable."

Vertebrate paleontologists studying the Great American Interchange between North and South American faunas since the closure of the Panamanian landbridge 2.5 million years ago also challenged the earlier static view. They postulated instead in general terms continuity and wide distribution of rainforests in tropical latitudes during humid phases alternating with widespread savanna habitats during dry phases (Webb, 1991; Webb and Rancy, 1996). During the latter periods, four principal effects influenced landscapes (Clapperton,1993): A reduced mean annual discharge of the rivers because of an overall reduction in precipitation; vertical incision and enhanced canalisation of rivers in their lower portions; a reduced vegetation cover over parts of the tropical lowlands; greater seasonality and more torrential run-off on the less protected slopes. Savanna communities appeared, where annual precipitation fell below 1,500 $\mathrm{mm}$ and a pronounced dry season existed.

During dry climatic periods of the late Tertiary Quaternary, extensive humid forests probably survived in those regions of the Amazonian lowlands, where enough surface relief was present to create rainfall gradients, e.g. near the rising Andes, on the northeastern (windward) flanks of the Guianan highlands that were being uplifted and eroded during the Tertiary-Quaternary, as well as in Rondonia (to the north of the Parecís mountains in central Brazil) and in the hilly areas of eastern Pará (Haffer, 1969; 1974; 1982; Vanzolini, 1970; 1973; Vanzolini and Williams, 1970; Brown et al., 1974; Prance, 1982; 1996). The species composition of the faunas in forest refugia probably was not stable (compared to the regionally more continuous rainforests during humid phases), but the refugia provided suitable habitat for lowland rainforest animals to survive adverse climatic periods. I should also mention that the complex fluvial dynamics continued to operate in the more or less extensive forests of the refugia. A forest refuge may not have consisted entirely of closed rainforest but, at least partially, of a mosaic of extensive patches of forest and savanna communities, as suggested by fossil mammals found in the upper Rio Napo region of eastern Ecuador (Rancy, 1991; 1993; Webb and Rancy, 1996). General reviews of the Refuge hypothesis as a macroevolutionary "habitat theory" were published by Vrba $(1992 ; 1993 ; 1995)$ who analyzed the evolutionary "turn-over pulses" of African faunas associated with climatic-vegetational fluctuations of the Tertiary-Quaternary.

The origin of the complex hilly or mountainous surface relief in peripheral regions of Amazonia due to tectonic uplift and erosional activity during the Tertiary (Andes, tepui mountains in southern Venezuela, table mountains in central Brazil, etc.) is seen as a precondition for the formation of forest refugia. The geological movements leading to the formation of the mountains around Amazonia by themselves (without the effect of climatic oscillations) and the effect of climatic fluctuations by themselves (without the surface relief) are each considered insufficient to explain the geographical isolation and speciation of Amazonian vertebrate populations. Rather, the developing complex geological structure and surface relief in peripheral regions of Amazonia (creating 
geographical rainfall gradients) in combination with the effect of global climatic fluctuations during the Cenozoic are the basic factors under the Refuge hypothesis that caused ecological vicariance of vertebrate populations.

Dry forests and gallery forests probably existed in the regions between the postulated humid rainforest refugia, where variously extensive wooded savannas and gallery forests dominated the landscape, as suggested by fossil mammals found in the Acre region of western Brazil (Rancy, 1991; 1993; Webb and Rancy, 1996; Latrubesse and Rancy, 1998) and by palynological data from the upper Rio Madeira region (Van der Hammen and Absy, 1994). Gallery forests, of course, also served as refugia for some tropical forest biotas in open regions during dry climatic phases (Meave et al., 1991; 1994). Their significance as centers of differentiation and speciation, however, remains open.

The dry transverse belt that crosses central Amazonia in a NW-SE direction separating humid upper and lower Amazonia (Figure 4) was probably the center from which dry climates spread westward and eastward during dry phases of the last several million years. Dense lowland rainforests probably disappeared from most of this dry transverse belt (Lauer 1988, Clapperton, 1993 and other authors) which includes the mountainous Pantepui region of southern Venezuela. This region had a very dry climate during glacial periods of the Pleistocene (Schubert et al., 1994; Schaefer and Dalrymple, 1995). However, small pockets of montane forest probably were preserved on high protected slopes of the tepui table mountains (collectively designated as "Pantepui refuge" ${ }^{\S}$. It is inconceivable that the endemic fauna of these montane forests should have developed only in post-Pleistocene time. On the other hand, the present lowland forest fauna of the Pantepui region shows every sign of a mixed upper Amazonian and Guianan origin. Its faunal elements reestablished contact in the lowlands between the tepui mountains when lowland forests reoccupied these regions upon the return of humid climatic conditions.

In addition to global climatic oscillations also more localized tectonic movements led to the formation of ecological refugia (Haffer, 1990). In different parts of the world (Andes, Brazil, Himalayas, etc.), rising mountain ranges or subsiding basins caused climatic changes in the lowlands at the leeward sides of the mountains which led to extensive vegetational changes on a more local scale (rain shadow effect). Refugia originated for different geological and paleoclimatic reasons during many periods of the history of the earth. Regarding the interaction of the degree of topographic diversity of a landscape, climatic fluctuations and speciation see also the discussions by Fjeldsa (1992), Vrba (1993) and Vrba et al. (1995).

\footnotetext{
$\S$ Schubert et al. (1994) mistakenly believe that the term "Pantepui refuge" refers to relict rainforests in the tropical lowlands between the table mountains. This is a misunderstanding. The term is applied to montane forests along the slopes of the tepui mountains in southern Venezuela.
}

Investigators in the tropics analyzed data sets from two independent sources - first, from geoscientific studies (palynology, geomorphology, paleoclimatology, rainfall distribution in relation to the surface relief) and, second, from biogeographic studies (e.g. the mapping of areas of high biotic endemism and regions of secondary contact between closely related taxa). The coincidence between conclusions derived from these two independent sets of data led to the formulation of the general hypothesis (Haffer, 1969; Vanzolini, 1970; Vanzolini and Williams, 1970; Simpson and Haffer, 1978; Haffer, 1982; Whitmore and Prance, 1987). It is incorrect when recent authors state that the Refuge hypothesis was initially based on biogeographical data alone.

A number of problems with the Refuge hypothesis that need to be taken into consideration may be summarized as follows: (1) Large gallery forests could promote gene flow between refugia and reduce the amount of differentiation; (2) humid forests between refugia may, at times, have been replaced by dry forest (rather than nonforest vegetation); (3) geoscientific evidence only suggests that there were climatic-vegetational changes in Amazonia, not that these changes did actually cause speciation; (4) only ecologically fairly narrowly adapted forest species were affected, whereas populations of ecologically more flexible species may not have been effectively isolated in the refugia.

Lynch (1988) analyzed the components of the Refuge hypothesis in a clear manner and suggested several tests or at least partial tests which, however, will be difficult to apply in view of the complexities of the geological history of Amazonia and the cyclic nature of the numerous climatic-vegetational changes in the Neotropical Region. Considering the present lack of detailed knowledge of the sequence of refuge formation, even conflicting cladistic data sets of animal groups would not, at this stage, "falsify" the model in its entirety. Generally speaking, any test of this hypothesis should be based on realistic criteria such as, e.g., that the faunal differentiation in refugia took place during the course of most or all of the Cenozoic and that the populations of a particular refuge reached very different levels of differentiation (subspecies, species) during a certain period of geographic isolation; or that some species remained more or less restricted to the area of a refuge after the return of humid climatic conditions.

A vicariance analysis of 13 clades of Amazonian birds from four families supported only two patterns for the historical interrelationships of forest areas of endemism, i.e. primary upper-lower Amazonian vicariance and primary Guianan vicariance (Prum, 1988). Climaticvegetational fluctuations are a likely cause of these series of vicariance events. Jégu and Santos, GM. (1993) similarly analyzed the phylogenetic relations and distribution patterns of rheophilous species of Amazonian fishes (Serrasalmidae) and interpreted the East-West and North-South vicariance events in terms of glacial-interglacial sealevel fluctuations. During glacial periods, the 
lowering of the sealevel increased the areas along rivers forming rapids and permitting the range expansion of rheophilous species. During interglacial periods, the rising sealevel caused the retreat to and increased isolation of rheophilous fishes in the headwaters of the rivers. Other fishes may have speciated in a converse mode during periods of lowered sealevel when small populations were isolated in portions of the former riverbed and were united again, when sealevel rose and warm-humid climates returned. Two additional observations may be related to this scenario: No fish species are endemic to the floodplains of the Solimões and Amazon Rivers, all species of the floodplains being derived from forest streams, open river waters, etc. (Hamilton pers. comm.). Moreover, the decreasing amount of fossil pollen from floating meadows over the last 9,000 years (Absy, 1979) may indicate that few or no floodplains existed during the last glacial period of lowered sealevel, when the Amazon River flowed in a rather narrow deep "canyon." Huber (1998) also hypothesized that climatic-vegetational fluctuations have been the major driving force for speciation in the Amazonian fish faunas during the Cenozoic, particularly the cyprinodonts which he studied in detail.

The Refuge hypothesis proposes a plausible mechanism of faunal differentiation in the tropics and in higher latitudes through the formation of ecological refugia due to Milankovitch cycles during the Tertiary and Quaternary and superimposed on a global cooling trend (see Discussion). This is a predictably reversable driving mechanism in the order of tens to hundreds of thousands of years, consistent with the rate of biological diversification (Terborgh, 1992). The refugia presumably served as "species traps" and "species pumps". This historical model appears capable of explaining the origin of the high tropical species diversity as compared to the less diverse faunas of the arctic and boreal biomes. The main factors are (a) the larger geographical area of tropical continents compared to continental areas in the Temperate Zones and (b) the much longer time span since the "accumulation" and diversification of species began in the tropics during early Tertiary times (and before) compared to the Temperate Zones (which became temperate only during the late Tertiary global cooling trend; Shacklton et al., 1990). As a consequence, global climatic-vegetational fluctuations generated a greater number of isolated habitat fragments (refugia) during each of the many Cenozoic climatic reversals in the tropics than in higher latitudes. By generating more isolated populations (and thus, on average, more new species) per unit of geological time, evolution proceded "faster" in the tropics, although the speciation process itself, of course, has always proceeded in an identical manner in tropical and extratropical faunas of the world.

The basic assumptions under the Refuge hypothesis are (1) the fragmentation of the Guianan-Amazon forests into (few to many) more or less separated humid forest blocks of different sizes during dry climatic phases of the Tertiary and Quaternary and (2) the differentiation of animal populations isolated in these refugia. The first assumption is, strictly speaking, a geoscientific problem that will eventually be clarified by geoscientific (and palynological) data. The second assumption will have to be evaluated in detail once enough geoscientific data document the presumed fragmentation of the forests. Biological clocks giving old speciation dates do not falsify the mode of speciation in a refuge but falsify only an assumed Pleistocene age of the event. The species under consideration may have originated in older refugia during a period of forest reduction during the Tertiary. The Refuge hypothesis refers to a particular mode of allopatric speciation, but not to a particular time of differentiation.

\subsection{New evidence for the effect of dry climatic periods in Amazonia during the quaternary}

Although the data base documenting dry climatic periods and corresponding vegetational changes in Amazonia is still scarce, especially regarding the Tertiary, a number of interesting reports have been published in recent years (Figure 5). Additional geological and geomorphological evidence from Amazonia and other portions of tropical South America was reviewed earlier by Ab'Saber (1982), Bigarella and Ferreira (1985), Haffer (1987a), Schubert (1988), Clapperton (1993), Hooghiemstra and Van der Hammen (1998), Burnham and Graham (1999) and Thomas (2000). This data, to-

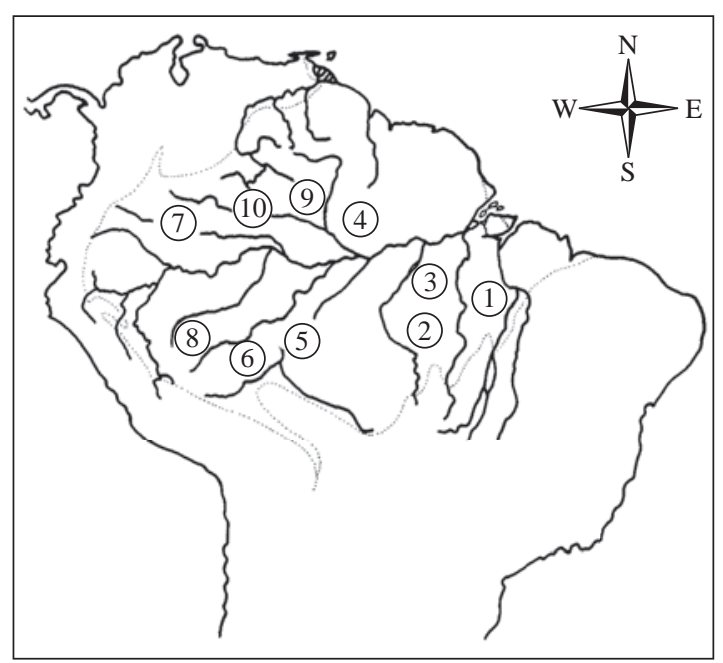

Figure 5. Location map of areas in Amazonia where additional paleoecological data have been discovered in recent years. A rich data base for Quaternary climatic-vegetational shifts is also available from northern South America and from various portions of Brazil outside Amazonia (not indicated on this map). 1 - Serra dos Carajás, 2 - Serra do Cachimbo region, 3 - lower Rio Tapajós region, 4 - Pitinga region, 5 Porto Velho and Humaitá region, 6 - Rio Acre region, 7 - middle Rio Caquetá region, 8 - upper Rio Juruá region, 9 - Rio Aracá-Rio Branco region and 10 - Lake Pata region. Stippled line follows the approximate outer limit of the Guiana-Amazon forest region prior to recent deforestation. 
gether with the new results summarized below, may be considered as a geoscientific test of the Refuge hypothesis. It is remarkable that nearly all geoscientists who published the results of their field studies in recent years (whether they are geologists, geomorphologists, geographers, palynologists, geochemists or paleontologists) agree on the basic premise of the Refuge hypothesis, i.e. a strong effect of vegetational shifts in Amazonia caused by periods of dry climates during the geological past (except Colinvaux et al., 2000). Absolute dates of many relevant deposits and events are still unknown; however, at this stage it was important to establish whether or not vegetational changes occurred in Amazonia at all. Details of mapping of past vegetation zones and dating of climatic phases will follow in later decades.

Large fossil dune fields have been discovered in the Rio Aracá-Rio Branco region of northcentral Amazonia (Figure 5, n. 9; Santos et al., 1993). The rainforests at Pitinga, ca. $250 \mathrm{~km}$ north of Manaus (Figure 5, n. 4) is underlain by strata that contain coarse and extremely poorly sorted layers that have been deposited under semiarid climatic conditions of the Late Pleistocene, when dense rainforest was absent from most of this region (Veiga et al., 1988). The same interpretation applies to portions of southern Brazilian Amazonia (Xingu, Teles Pires-Juruena, middle Tapajós and northern Rondonia; Veiga et al., 1988, Bettencourt et al., 1988, Veiga, 1991). Similarly, in the middle Rio Tapajós region (Figure 5, n. 3) and in the lowlands around the Serra do Cachimbo (Figure 5, n. 2), coarse debris accumulated in surface depressions during a period of strong erosion, when the late Quaternary climate was semiarid and rainforest vegetation had largely disappeared from these regions (Bibus, 1983). The nature and widespread occurrence of these coarse deposits in lower Amazonia preclude their interpretation as being solely due to steepening of the erosional gradient when sealevel was low during the last glacial period, but under a humid rainforest vegetation similar to that which covers these regions today. Geomorphological observations in Rondonia (regions of Porto Velho and Humaitá; Figure 5, n. 5) by Emmerich (1988) also indicate a semiarid climate and open vegetation in this portion of southern Amazonia during the late Tertiary and during dry climatic phases of the Pleistocene. Pollen data indicate that savanna vegetation was widespread in the area to the southeast of Porto Velho, Rondonia and in other portions of Amazonia during the last glacial maximum (Van der Hammen et al., 1994, Hooghiemstra and Van der Hammen, 1998; see also Freitas et al., 2001, regarding post-Pleistocene vegetational changes in this region). Throughout the Acre Subbasin (region of the upper Rio Purús and lower Rio Acre; Figure 5, n. 6), gypsum and aragonite precipitates associated with finegrained sediments indicate the desiccation of an extensive fluvial-lacustrine system due to dry climatic conditions about 53,000 years ago, i.e. during the late Pleistocene
(Kronberg et al., 1990; 1991) ${ }^{\text {Il }}$. Moreover, paleontological studies of fossil mammals indicate that a vegetation consisting of wooded savannas and gallery forests was widespread in western Amazonia, especially in the upper Rio Juruá region, during portions of the Pleistocene before dense rainforests again covered this area completely (Figure 5 n. 8; Rancy, 1991; 1993; Webb and Rancy, 1996). Most of these fossil sites fall between the main postulated forest refugia (Figure 1f), but those along the upper Rio Napo in eastern Ecuador are located in peripheral portions of the Napo forest refuge area.

The relatively small plateaus of the Serra dos Carajás, State of Pará (Figure 5, n. 1) are covered today on top with open canga vegetation and are surrounded on all sides (including the slopes) by dense rainforests. Geological and paleopollen analyses of a core collected in a swamp on one of the plateaus revealed four periods of rainforest regression from this general region during the last 60,000 years (Absy et al., 1991; however, see critical remarks by Colinvaux et al., 2000). A semi-quantitative and dynamic approach in modelling a scenario for a "dry" climatic phase in central Amazonia below Manaus led Iriondo and Latrubesse (1994) to conclude that this region had a general savanna character and that only second-order changes in the regional dynamics are needed for the occurrence of a dry climatic phase. Based on the observation of sharp slope dissection in central Amazonia, Tricart $(1974,1985)$ had earlier stated that, during the last glacial stage, this region was not covered by rainforest but by drier vegetation types under which runoff was able to produce dense slope dissection.

On the other hand, a pollen record from Lake Pata in northwesternmost Brazil (Figure 5, n. 10; Colinvaux et al., 1996) confirmed the prediction of the Refuge hypothesis that this region near high surface relief remained densely covered with humid tropical forests during the last cool-dry glacial maximum (Imerí Refuge; Haffer, 1969). Serra da Neblina (up to 3,014 m) and Serra Imerí (over 2,000 m) near Lake Pata in the border region between Venezuela and Brazil certainly caused a strong rainfall gradient during dry periods of the geological past. Colinvaux et al. (1996) greatly overinterpreted their palynological results, when they claimed the Lake Pata pollen record proved that most or all Amazonia was cool and humid during the last glacial maximum. In order to test the Refuge hypothesis, sampling sites between (not within) postulated forest refuge regions need to be selected (see also Hooghiemstra and Van der Hammen, 1998: 157).

In upper Amazonia, coarse gravels occur within terrace sediments along the Rio Caquetá, Colombia (Figure 5, n. 7) and indicate temporary aggradational

II Räsänen et al. (1995) treated sediments exposed in the upper Purus-Acre region as of late Miocene age. Additional studies are needed to verify the Quaternary age of the strata sampled by Kronberg et al. (1.c.) and the Tertiary age of the sediments studied by Räsänen et al. (1.c.). 
conditions markedly more torrential than those currently prevailing along this river (Eden et al., 1982). These gravels may be interpreted to indicate periodic phases of dry, or at least strongly seasonal, conditions in the Andean headwater region. On the basis of pollen data from the middle Rio Caquetá region, Van der Hammen et al. (1994) concluded that, during drier intervals of the middle Pleniglacial, savanna-caatinga-type vegetation could develop or extend somewhat locally. Paleoclimatic data from two ice cores taken in the Andes of Peru led Thompson et al. (1995) to conclude that the Amazon basin forest cover probably was markedly reduced (more patchy) during the last glacial stage than it is today.

The results reviewed above indicate strong vegetational shifts in many regions of Amazonia due to alternating dry/humid climatic phases. In other words, the Refuge hypothesis so far withstood the test by geoscientists (who failed to falsify its geological premises, the claims of Colinvaux et al. (2000) notwithstanding). Presently available geoscientific data are still insufficient to allow for the precise mapping of changes in distributions of forest and nonforest vegetation during the various climatic periods and, in particular, for the tracing of the size and location of areas of relictual humid forests and savannas that presumably served as refugia for the Amazonian fauna and flora during adverse climatic periods of the Tertiary and Quaternary. Similarly, Burnham and Graham (1999: 569-570) concluded their excellent review stating: "There are a number of indications that late Glatial and early Holocene climates in the neotropical lowlands included cooler and drier intervals, and variously supported a mosaic of moist forests and drier forests to savanna-like vegetation. These are: (1) fossil mammalian faunas in Central and South America [...]; (2) a trend toward drier conditions and a more complex array of communities developing near the end of the Tertiary Period in Costa Rica and Panamá [...]; (3) aridity at interglacial-glacial transitions in Guatemala [...]; (4) geomorphic features suggesting aridity during the Quaternary in the Amazon lowlands [...]; (5) marked changes in sea level [...]; and (6) Quaternary aridity demonstrated from other adjacent and distant parts of the word $[\ldots]$. ... The combination of temperatures ca. $6{ }^{\circ} \mathrm{C}$ cooler (during the last glacial maximum), sea level ca. $120 \mathrm{~m}$ lower and pollen sequences indicating a least locally habitats and open vegetation are compeling. They create at a view of lowland neotropical vegetation alternating between closed forest and more dry open forest or savanna-like vegetation during the environmental fluctuations of the late Tertiary and Quaternary Period."

\subsection{Recent discussions of the refuge hypothesis}

In view of much supporting geoscientific and biogeographic evidence, numerous authors discussed the Refuge hypothesis favorably in interpretations of their own results of systematic and biogeographic studies in the Neotropics, e.g. several contributors to multi-author volumes (Duellman, 1979; Prance, 1982; Mares and
Genoways, 1982; Prance and Lovejoy, 1985; Whitmore and Prance, 1987), as well as Terborgh (1992) and Vanzolini (1992). Fjeldsa (1994: 219) concluded that Neotropical species probably "differentiate by isolation of relict populations in places which remained ecologically stable, and within geologically well structured regions at the periphery of an old biome" (such as Amazonia).

Reviewing geological data of the Quaternary from all over tropical South America, several geomorphologists supported the basic premises of the Refuge hypothesis. Garner (1974: 238-239; 1975) concluded that "dry conditions with sparse vegetation invaded many humid tropical lowlands during [glacial periods] ... In effect, the lands, apart from high mountains, seem to become dry from the bottom up and moist from the top down." Lauer (1988) and Clapperton (1993a,b) emphasized the increased dryness of the South American continent during glacial periods of the Pleistocene, when humid rainforests retreated from portions of Amazonia and were replaced by dry forests and nonforest vegetation, especially along the dry transverse belt in middle and lower Amazonia. This led to a separation of a large forest block covering western and southcentral Amazonia from the forests along the windward northeastern flank of the Guiana highlands. As Clapperton (1993a: 215) stated, "species of most rainforest plants and biological life would have found refuge in these areas, along with displaced populations from higher up the slopes."

I agree with this "coarse-grained" scenario but would like to point out that the forests of southcentral Amazonia in Rondonia, and those near the base of the Andes in eastern Peru (Inambari refuge) and eastern Ecuador (Napo refuge) probably were separated, at times, from one another by drier types of vegetation. Moreover, additional large humid forested areas probably existed in the hilly region to the south of the mouth of the Amazon River (Belém refuge) and around the Serra da Neblina - Serra Imerí that rise to over 3,000 $\mathrm{m}$ a.s.1. in the border region of Venezuela and Brazil (Imerí refuge).

Several other authors directed critical comments at distorted caricatures of the Refuge hypothesis stating, e.g., that it refers to a single, fairly recent vicariance event, and that it claims the diversification of the entire Neotropical biota is the result of habitat fragmentation exclusively during the Quaternary. These claims are not part of the refuge model. Other authors based certain "tests" of the Refuge hypothesis on totally unrealistic criteria none of which had ever been stipulated as defining properties of this model, or they mistakenly assumed a lowland location of certain forest refugia when montane forests on mountain flanks were implied, e.g. in the Venezuelan Andes and the Guianan highlands (see Haffer 1993, for a discussion of some of these criticisms). As mentioned above, broad gallery forests and locally humid conditions probably existed along major river valleys of those regions in Amazonia that were affected by generally dry climatic conditions. Therefore, humid 
conditions, e.g., along the middle Amazon River during the last glacial stage, cannot be considered as evidence against the reduction of humid rainforest cover over certain portions of Amazonia (as opposed to Müller et al., 1995). For over 30 years, the probable existence of a series of Pleistocene forest refugia in the Pacific and Caribbean lowlands near the Middle American mountain ranges has been discussed. The results of a recent study by Aide and Rivera (1998) on the genetic diversity in Central American plants (Poulsenia) are entirely consistent with this hypothesis (or with the persistence of this plant in humid riparian zones). No author ever claimed that tropical forests were eliminated completely from the Middle American land bridge during dry periods of the Pleistocene (supposedly deriving extant plant and animal populations in Middle American forests all the way from Amazonia, as Aide and Rivera, 1.c., implied).

Below I criticize several sweeping and unwarranted conclusions of Colinvaux et al. (2000) regarding a continuous forest cover of Amazonia during the last glacial period of the Pleistocene. In order not to be misunderstood I emphasize the value of the hard data that these authors collected in various regions of Amazonia during recent years. Only by continuing field work will we eventually get a clear understanding of the effect of climatic-vegetational changes in Amazonia during the Tertiary and Quaternary. Until then the best we can do is to compare the data base at hand with our models and to make certain suggestions but leave the final answer to the future. The claim of Colinvaux et al. (2000) that for Amazonia "the aridity and refuge hypotheses have failed" appears unjustified in view of the fact that these authors ignored the majority of geomorphological data indicating an effect of dry climates during the history of Amazonia. (As repeatedly mentioned it is appropriate to speak of dry rather than arid climatic periods). If they are of the opinion that these data are not valid, then this needs to be explained and discussed.

\subsection{Palynological data}

The three data points from the Amazonian lowlands (and one sample location offshore) available to Colinvaux et al. (2000) are clearly insufficient for an interpretation regarding a complete forest cover of Amazonia during the last glacial period (the refuge theory also predicts the existence of large forested areas in the lowlands). The Lake Pata pollen profile near the Imerí range (3,000 m elevation) of northernmost Brazil cannot be used as "proof" against the refuge model (as was done by Colinvaux et al., 1996; 2000), because this region had been predicted to be forested during glacial periods by supporters of the refuge theory for many years ("Imerí refuge," Haffer, 1969). Hooghiemstra and Van der Hammen (1998: 157) and Burnham and Graham (1999: 568) raised basically the same argument in their wideranging reviews which were also ignored by Colinvaux et al. (2000).
The finding that the forest on the eastern slope of the Ecuadorian Andes at an elevation of around 1,000 m, during the last glacial period, was a moist forest with Andean elements is interesting but hardly surprising in view of the altitude of the sample locations near San Juan Bosco and Mera above the Amazonian lowlands and in view of previous palynological data from the Colombian Andes. These results cannot be taken as "directly falsifying" the prediction of the refuge theory that extensive forests suitable for lowland rainforest faunas (Napo refuge) existed at the eastern base of the Ecuadorian Andes below $500 \mathrm{~m}$ elevation during dry glacial periods.

Regarding the results of pollen analyses of marine sediment cores from off the mouth of the Amazon River (Haberle and Maslin 1999), there are several reasons to doubt the value of the pollen signal, as discussed by Hooghiemstra and Van der Hammen (1998): (1) graminaceous pollen grains may be derived from savanna-like vegetation or from floating grass-rich meadows; (2) mixing and redeposition of sediments during glacial sea-level stands that were up to $120 \mathrm{~m}$ lower than today; (3) large gallery forests along the river courses in Amazonia probably prevented pollen grains from savanna vegetation to reach the river system. Savanna vegetation is expected to be poorly represented in the river-transported pollen spectrum. According to Hooghiemstra and Van der Hammen (1998) the conclusions of Colinvaux et al. (2000) with respect to a stable rainforest cover of Amazonia since the last interglacial period are unjustified.

Van der Hammen and Hooghiemstra (2000) reviewed the available palynological data regarding the Late Tertiary and Quaternary history of vegetation and climate in Amazonia. They estimated that rainfall during the last glacial maximum may have been reduced by $30-50 \%$ leading to extensive shrinkage of wet rainforest and the formation of wet forest refuges. Similarly, the oxygen isotopic composition of planktonic foraminifera recovered from a marine sediment core in a region of Amazon River discharge shows that the Amazon Basin was extremely dry during the cool Younger Dryas (ca. 12,000 Years Before Present), with the discharge reduced by at least $40 \%$ as compared with that of today; effective moisture increased steadily afterwards during the Holocene (Maslin and Burns, 2000). Moreover, probably in none of the published records from Amazonia and central Brazil are sediments of the Last Glacial Maximum (LGM) present or abundant (Ledru et al., 1998; Van der Hammen and Hooghiemstra, 2000 for Lake Plata). The LGM was represented probably by a hiatus of several thousand years or more, indicative of drier climates than before or after; "sediment changes attest to drier climates between ca. 24,000 and 17,000 YBP" (Ledru et al., 1998: 236).

\subsection{Geomorphological data}

Colinvaux et al. (1.c.) ignored the results of much early field work reviewed by several authors previously and also most of the more recently collected data sum- 
marized above. Hopefully, these authors will take such data into considerations in future publications. This also applies to the results of geomorphological and palynological work in other tropical regions of the world (Africa, Malay Archipelago, New Guinea) which, like in Amazonia, point to massive climatic-vegetational fluctuations in these regions too. Colinvaux's (1998) theory of cool, $\mathrm{CO}_{2}$ deficient "islands" in peripheral portions of Amazonia, if valid, would apply only to the Quaternary but not to the generally warm Tertiary period (when drywet climatic fluctuations probably affected Amazonia causing most speciation and faunal differentiation).

\subsection{Biological arguments}

Whether or not the fossil mammals from upper Amazonia required a fairly open habitat (Webb and Rancy, 1996) or were able to survive on the vegetation of a forest river (Colinvaux et al., 2000), is best left to the judgment of the paleontologists (see above). Vegetational changes by Milankovitch cycles of Quaternary and Tertiary age presumably initiated many speciation processes which may have been completed during one, two or even three cycles. There is no correlation between Milankovitch cycles and the duration of the speciation process (the latter depending on the size of a given isolated population, the degree of separation and other factors). Once a new species has originated, it will survive several or many climatic cycles until it splits into two new species or buds off a new species. Refuge theory refers to the postulated origin of species in ecological refugia irrespective of the geological time periods. Milankovitch cycles in the time range of speciation processes probably caused climatic fluctuations during the Quaternary as well as during the much longer Tertiary and earlier geological periods (Bennett, 1997). Refuge theory does not refer to a particular time of speciation but to a particular mode of speciation.

Colinvaux et al. (2000) concede a somewhat drier Amazon region during glacial times leading to some shrinkage of the forest along peripheral portions of Amazonia and Bush (1994: 11) accepted the fragmentation of the Amazon forest into at least two blocks in upper (western) and lower (eastern) Amazonia, respectively, both separated along the NW-SE transverse dry belt across lower Amazonia. I am confident that the differences in interpretation that exist under the disturbancevicariance theory (see below) and under the refuge theory will diminish as more field data will be collected. However, prejudiced and selective commentaries like, e.g., that of Willis and Whittaker (2000) are not helpful in this debate.

Generally speaking, the Refuge theory refers to paleoecological changes due to Milankovitch cycles and their effect on biotic differentiation during the entire Cenozoic (at least 60 million years), whereas the hypothesis of Colinvaux (1993, 1998; Colinvaux et al., 2000) refers to the last two million years only. These theories are not alternatives concerning, respectively, the period of main biotic differentiation (Refuge theory) and that of late speciations and post-speciational adjustments of biotic distributional patterns (Disturbance-vicariance theory).

\section{Canopy-density Hypothesis}

Recent modeling research investigated possible responses of vegetation in the Amazonian lowlands to the climate of the last glacial maximum (LGM), focusing on the balance between changes in vegetation type and structure (Cowling et al., 2001). Most of the simulated $20 \%$ decrease in forest cover during the LGM occurred near the southern margins of the basin and several localized regions of xeric vegetation types were introduced within central Amazonia. The results also suggest repeated reductions and increases in forest canopy density over large areas during glacial-interglacial cycles. Alterations in the canopy microclimate were probably brought about by glacial cooling, aridity, and low concentration of atmospheric $\mathrm{CO}_{2}$ leading to individualistic changes in the distribution of plant and animal species. During glacial periods, forests with reduced canopy humidity and relatively high temperatures probably had a wider distribution than today which may have led to interruption of gene flow (vicariance) in many species and subsequently to speciation. Under this hypothesis, biological separation of gene pools does not necessarily require forest fragmentation but only a change from wet to dry forests. This hypothesis applies not only to the Pleistocene but also to much earlier periods in the Cenozoic, because forests are independently (and interactively) influenced by decreases in atmospheric $\mathrm{CO}_{2}$, temperature, and precipitation. Paleoclimate reconstructions indicate that relatively low $\mathrm{CO}_{2}$ concentrations and high temperatures could have resulted in large spatial variations in forest vegetation thereby geographically isolating species over time.

The canopy-density hypothesis is not very different from the Refuge hypothesis. Both models propose that large-scale vegetation changes occurred in Amazonia during periods of climatic changes (precipitation, temperature, $\mathrm{CO}_{2}$ ) leading to an expansion of dry-adapted forests and nonforest vegetation thereby causing separation of populations and corresponding speciation to occur. Both models refer not only to the Pleistocene but also to earlier geological periods. Based on geomorphological field data from central Amazonia and the wide distribution of savanna plants, the refuge hypothesis emphasizes a more widespread occurrence of open vegetation in Amazonia during certain dry climatic periods, whereas the simulations of Cowling et al. (2001: 142) introduced only "a few localized regions of xeric vegetation types" within central Amazonia during the LGM. However, in view of the fact that, under the refuge hypothesis, not only open vegetation zones but also regions covered with various types of dry forest and other types of intermediate vegetation acted as barriers for wet rain- 
forest animals and plants, both hypotheses have more similarities than differences.

\section{Museum Hypothesis}

This hypothesis postulates (1) speciation in very localized stable habitat pockets in mountainous regions around the periphery of Amazonia due to climatic fluctuations without major vegetational changes, (2) range expansion of new species into the Amazonian lowlands where they accumulate over geological time and are preserved as in a "museum." As additional species originate by vicariance in the foothill regions of the mountains, they spread again into the lowlands (Roy et al., 1997, Fjeldsa et al., 1999). These authors feel that, under their hypothesis, it is not necessary to invoke barriers of open vegetation to explain the isolation of populations of forest animals in the lower montane habitat pockets; "a specialised bird could also vanish over large areas because of increased species turnover resulting from high functional heterogeneity of habitats." Even if feasible on a theoretical basis, this hypothesis is contradicted by geoscientific field data documenting climatic-vegetational fluctuations in Amazonia (see above).

\section{Disturbance-Vicariance Hypothesis}

According to this hypothesis which refers to the Pleistocene only, "the prime environmental forcing of tropical forests in ice-age America was cooling rather than aridity... The forests of the central Amazon were probably not markedly fragmented, though savanna regions at the periphery were probably more extensive than now" (Colinvaux, 1993: 473, 485; 1996; 1998; Colinvaux et al., 1996; 2000). During the glacial periods of the Pleistocene, lowland biota are assumed to have inhabited the Amazonian bottomland (0 to $300 \mathrm{~m}$ above modern sealevel), where temperatures were ca. 5 degrees $\mathrm{C}$, at times 7 degrees $\mathrm{C}$, lower than at present. The peripheral portions of Amazonia that include the areas of faunal endemism are seen as $\mathrm{CO}_{2}$ deficient dynamic borderlands between the uplands and the bottomlands. In these regions species distribution and abundance oscillated throughout the Pleistocene due to invasion and counterinvasion. These intense species interactions are assumed to have favored species isolations and differentiation, thereby supposedly explaining how these regions became centers of speciation and endemism.

Under this hypothesis, the peripheral areas of Amazonia are expected to be especially rich in endemic taxa because of the supposed environmental instability of these regions (rather than the implied general ecological stability in the postulated humid forests under the Refuge model). In his global survey of the history of rain forests, Morley (2000: 279) is doubtful of "suggestions that areas of highest species-richness are not areas of maximum stability, but of maximum disturbance (e.g. Bush, 1994)". It is difficult to follow Colinvaux's reasoning, because he did not take into consideration almost any of the geoscientific data that suggest dry climatic conditions in peripheral and certain portions of central Amazonia (as reviewed above). This hypothesis (based exclusively on pronounced temperature oscillations) refers only to the Quaternary and, in contrast to the Refuge hypothesis, is not applicable to the intensive faunal differentiation during the generally warm Tertiary period (when most extant species originated). Thus these theories are not alternatives.

In his wideranging review, Bush (1994) also stated that climatic cooling, rather than aridity, was the factor driving a Pleistocene re-assortment of vegetation in Amazonia, although he did accept climatic drying (by about 20\%) over Amazonia during glacial periods, which led to the expansion of dry-adapted vegetation types into the transverse climatic belt crossing lower Amazonia from southeast to northwest in the Manaus-Santarém region, as well as crossing southwestern Amazonia along the border region of Peru and Brazil. In this way, Bush (1.c.) accepted a separation of humid rainforest blocks in the Guianas and at the mouth of the Amazon River from the upper Amazonian forests (as discussed under the Refuge hypothesis). Moreover, he speaks of species that "only survived in areas that were optimal." Apparently, Bush (1994: 13) had species-specific refugia in mind when he stated:

"If the cooling and drying stressed individual species to the point where they went extinct over parts of their range and only survived in areas that were optimal, a mechanism for allopatric speciation emerges. Each time a population was stressed by climatic change, and this may occur several times for each Quaternary glaciation, the chance of becoming fragmented increased, especially where it is in competition with species that are better adapted to the prevailing conditions. Species that contained considerable environmentally-related genotypic variation may have contracted into optimal locations for each genotype ... The presence of invading, cold-adapted, or dry-adapted taxa could have resulted in local competitive exclusion of some lowland taxa, or genotypes, further increasing the possibility of isolation and allopatric speciation."

It is evident that this generalized interpretation uses arguments derived from both the Refuge hypothesis (dry/ humid cycles) and the Disturbance-vicariance hypothesis (cold/warm cycles). As in the model of Colinvaux (1993, 1996), the question arises under Bush's interpretation as to the speciation mechanism during the Tertiary, when most species originated and when primarily dry/humid cycles occurred.

\section{Gradient Hypothesis}

This model predicts parapatric speciation across steep environmental gradients (boundaries) without the separation of the representative populations (Endler, 1982). Centers of diversity correspond with zones of 
relative environmental uniformity, and zones of biotic change correspond with zones of environmental change.

Mayr and O'Hara (1986) refuted this hypothesis with respect to the fauna of tropical Africa. Similarly, biogeographical data sets from South America do not support the Gradient hypothesis (Prum, 1988; Patton et al., 1992), whereas Mallet (1993) found "it is not easy to exclude parapatric differentiation" as a mode of speciation in Amazonian Heliconius butterflies (see, however, Futuyama and Shapiro 1995). Recently, Turner and Mallet (1996) suggested that mimicry rings in Heliconius did not originate via "biotic drift" in allopatry and in conjunction with Pleistocene climatic-vegetational fluctuations (as proposed by Brown et al., 1974), but rather by mutation and random drift in parapatry. Novel color patterns then spread to become predominant in local areas and later over wide areas by the migration of clines.

On the other hand, Brower (1996: 209-210) analyzing the mtDNA of Amazonian Heliconius species concluded: "The reduction of gene flow by Pleistocene vicariance provides a compelling explanation for the biogeographical concordance of diversified races in numerous unrelated Neotropical taxa in areas not currently separated by obvious barriers to dispersal ... The surprisingly similar branch lengths of haplotypes within unresolved clades, and the similarity of amounts of divergence both between clades within species and between comparable clades in $H$. erato and $H$. melpomene suggest that extrinsic forces experienced in common, simultaneously, and recently, promoted the radiation of phenotypes in both species. Pleistocene climatic changes that disrupted community structure ... could have released the two species from mimetic constraints and promoted concordant and rapid racial divergence, even in the absence of complete geographical isolation." A recent study by Schneider et al. (1999) on lizards of the Australian humid tropics indicated, however, that "natural selection operating across ecological gradients can be more important than geographic isolation in similar habitats in generating phenotypic diversity."

\section{An Example: Amazonian Forest Birds}

Below I discuss briefly the distributions and phylogenetic relations of the members of several widespread groups of forest birds to illustrate the conspicuous regional mosaic distribution patterns that originated through historical processes of barrier formation and speciation (see also Haffer, 1981; 1987b; 1997).

Pionopsitta species group (Figure 6): These mediumsized parrots inhabit the canopy level and travel above the treetops in noisy small groups. Three species subdivide Amazonia among themselves (Haffer, 1970; 1992; Cracraft and Prum, 1988). P. barrabandi occupies upper Amazonia, $P$. vulturina inhabits the region to the south and $P$. caica to the north of the lower Amazon River. The head is mainly black in these species (unfeathered in adult $P$. vulturina !) with yellow or orange markings; the body is green or bluish green. P. barrabandi has a yellow or orange yellow malar spot, the iris is dark brown and the bill blackish. In $P$. vulturina and $P$. caica, a collar is yellow and orange (or olive yellow), respectively, and the bill greenish gray, yellowish at the base of the upper mandible and horn color, respectively. Both these latter species have orange irides. On the other hand, the color pattern of the wing is very similar in P. barrabandi and $P$. vulturina (bend of wing and lesser wing coverts orange and the underwing coverts red); the underwing coverts are green as the body in $P$. caica. Based on the color of bill and iris and the presence of a collar, $P$. vulturina and $P$. caica appear to be more closely related than either is to $P$. barrabandi, whereas the pattern of wing color connects $P$. vulturina with $P$. barrabandi. Possibly, the red and orange color pattern of the wing was secondarily lost in the peripheral species $P$. caica and the former interpretation above is more likely.

The lower Amazon separates $P$. caica and $P$. vulturina, but the populations of $P$. barrabandi to the north and south of the Rio Solimoes are not taxonomically differentiated (they were previously believed to represent different subspecies). $P$. barrabandi meets $P$. caica in southern Venezuela and $P$. vulturina in southcentral Amazonia. In this latter region, $P$. barrabandi crossed the comparatively narrow upper Rio Madeira in a southeastern direction and occupied a large portion of Rondonia and of the headwater region of the Rio Tapajós. On the other hand, $P$. vulturina ranges along the the south bank of the Amazon westward to the right bank of the lower Rio Madeira and south to the upper Rio Tapajós and Rio Xingu. Both species evidently are here in parapatric contact; hybrids are not known. In central Amazonia, the wide lower Rio Negro separates $P$. barrabandi and $P$. caica and the lower Amazon the ranges of $P$. caica and $P$. vulturina.

If the lower Amazonian species P. caica and $P$. vulturina are indeed the closest relatives in this group (as argued above), then an earlier vicariance event separated upper and lower Amazonian ancestral forms before caica and vulturina differentiated in the regions to the north and south of the lower Amazon River, respectively. Probably, these parrots are ecologically incompatible and for this reason exclude each other geographically in areas where they come into contact. Broad river courses as "semi-barriers" stabilized the range boundaries between these competing species in various regions.

Selenidera species group (Figure 7): Five small toucanets replace each other in Amazonia, one species is found in southeastern Brazil and another one in Middle America (Haffer, 1974). They are characterized by yellow eartufts and inhabit the middle levels of humid forests. The two upper Amazonian forms (reinwardtii and langsdorffii) hybridize where they are in contact and may be still subspecies of one species. S. gouldii and $S$. maculirostris are also very closely related indicating historical connections between the forests of Amazonia with those of southeastern Brazil either via the forests 


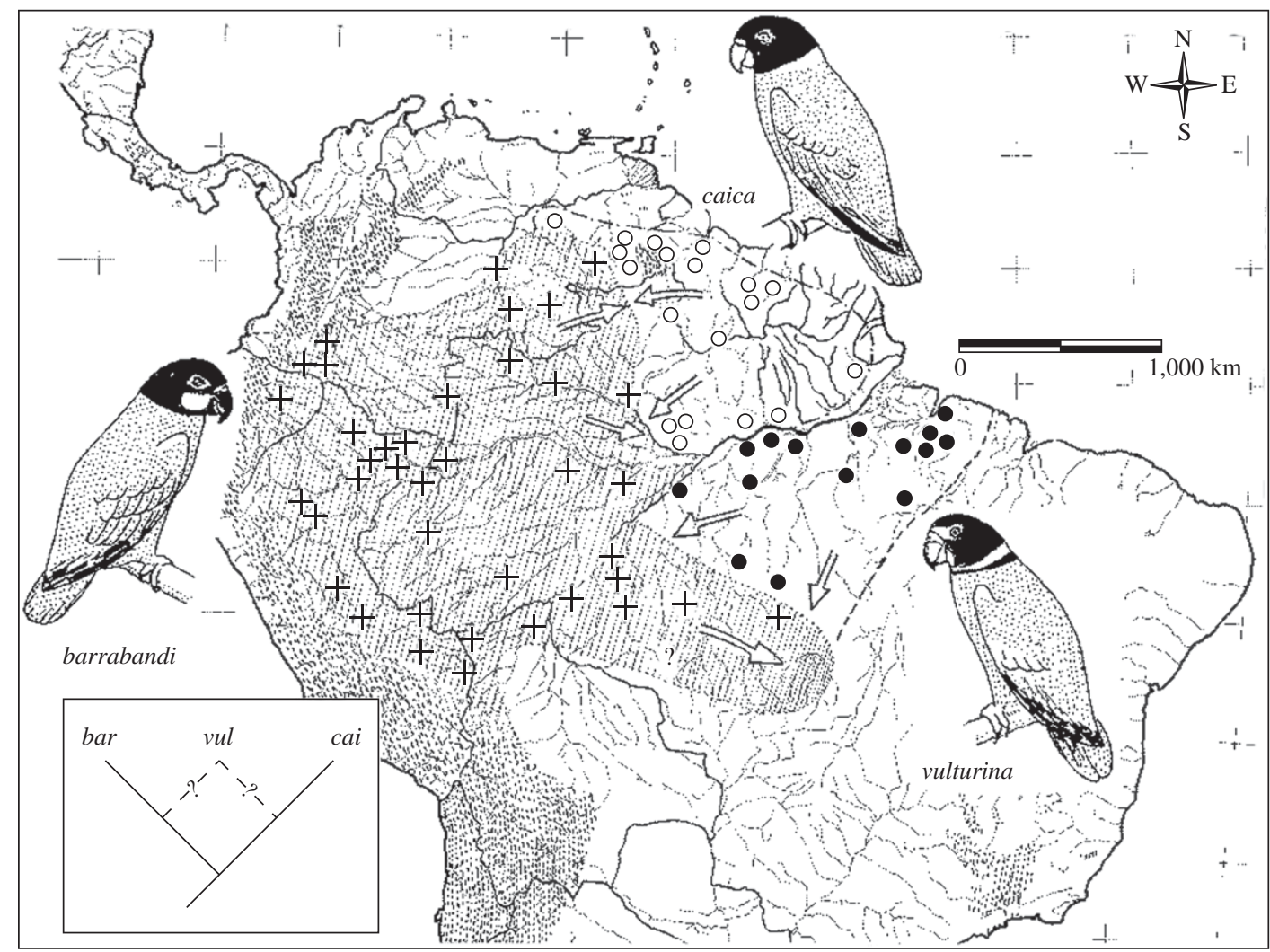

Figure 6. Distribution of the Pionopsitta parrots in Amazonia (updated from Haffer, 1970). Other representatives inhabit southeastern Brazil and Middle America. Plumage color code: Stippled - green or bluish-green, blank - yellow (collar, malar spot, bend of wing in two species), solid - black (head unfeathered in P. vulturina); symbols are locality records. At lower left corner schematic illustration of phylogenetic relations of species shown (see text for details).

along the Atlantic coast or across central Brazil (or both). The Amazon and Madeira Rivers as well as the lower Rio Negro separate the species inhabiting the forests on opposite riverbanks. On the other hand, S. nattereri/culik meet in southern Venezuela and S. nattereri/reinwardtii in southeastern Colombia; no details are known regarding their interrelationships in these areas. Phylogenetically, the trans-Andean S. spectabilis and S. culik are early isolates within this group. Whether S. nattereri is more closely related to the upper Amazonian forms or to gouldii-maculirostris remains unknown (Prum, 1988).

Ramphastos species group (Figure 8): The plumage of these toucans is mainly black; the upper tailcoverts are red, yellow, or white. Other differences among the various species and subspecies refer to the color of the throat and tail, the iris and the bill. Two distinct and widely sympatric species groups form mosaic distribution patterns over almost the entire Neotropical Region (Haffer, 1974). These assemblages are composed of (1) large, smoothbilled species with yelping calls ( $R$. tucanus group) and (2) medium-sized channel- or keel-billed species which have croaking vocalizations ( $R$. vitellinus group). The larger species inhabit the canopy level, whereas the smaller toucans live mostly at middle levels in the forest. Some of the geographical representatives of each group hybridize along their zones of contact, whereas others have reached the species level replacing each other without hybridization (parapatry). Both groups are represented by one form in upper Amazonia, the smaller toucans by two in lower Amazonia and the larger ones by one form only. Similarly, there are more forms of the smaller group in the rainforests west of the Andes (three) than of the larger toucans (one species).

The phylogenetic relations of the taxa included in the $R$. vitellinus group indicate that an early westeast separation (vicariance event) of upper and lower Amazonian forms preceded the later differentiation of the extant forms citreolaemus and culminatus in the west and vitellinus-ariel in lower Amazonia. R. dicolorus and the two trans-Andean species originated from stocks that separated prior to the differentiation of the Amazonian forms. The upper and lower Amazonian forms of the large smooth-billed species $R$. tucanus also document a separation of a western from an eastern population in Amazonia that later reestablished contact forming an ex- 


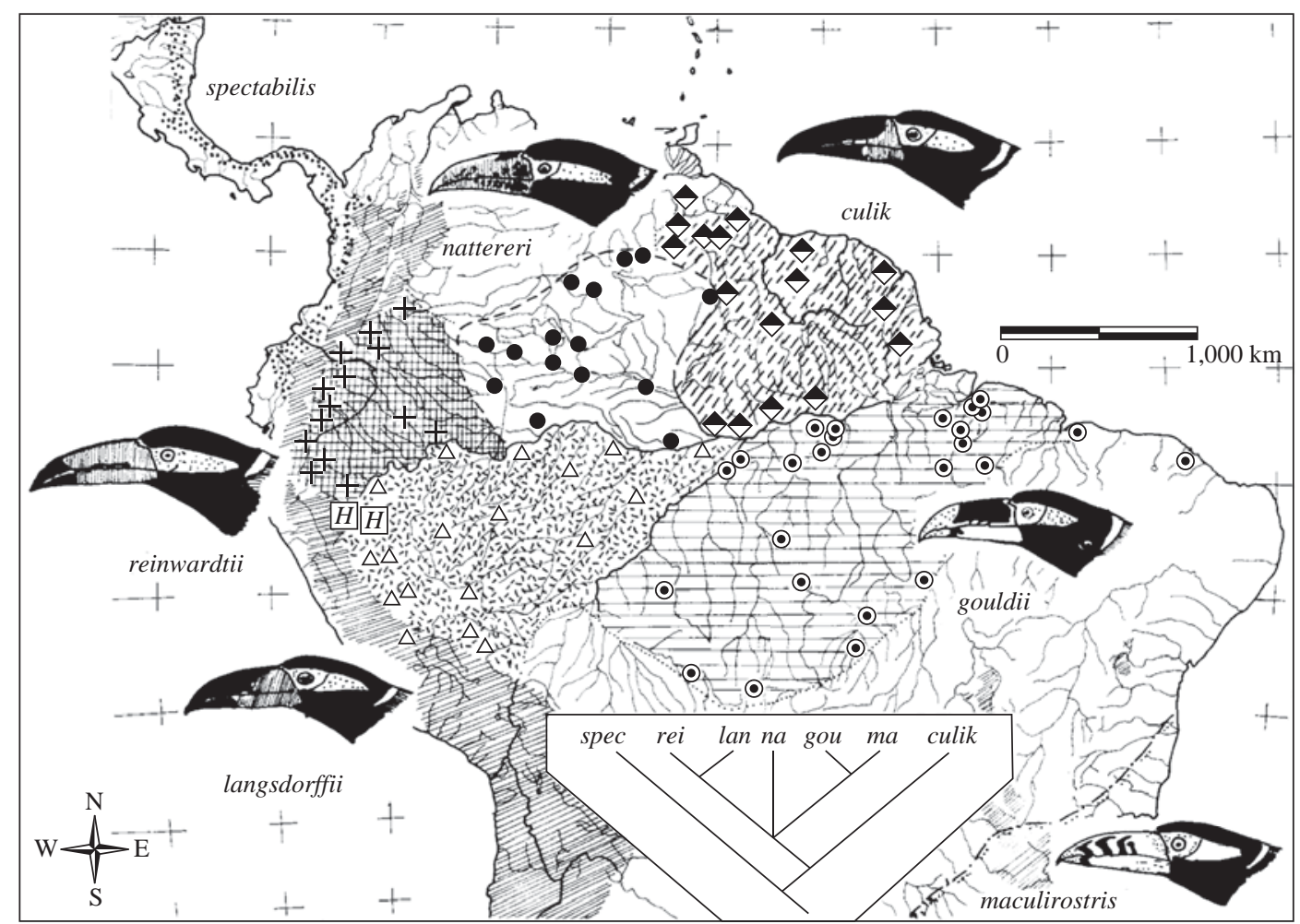

Figure 7. Distribution of the Lowland Toucanets Selenidera (updated from Haffer, 1974). Locality records (symbols) are given for the five Amazonian species; the two upper Amazonian forms hybridize where they meet $(\mathrm{H})$ and are often treated as subspecies of one species. Color code for color of plumage and bill (adult male): stippled - yellow, hatched vertically - red, hatched obliquely - light green, blank - white. S. nattereri has several small blue marks on the sides of both mandibles near the base. Phylogenetic relations of taxa (bottom) are schematically illustrated after Prum (1988).

tensive hybrid belt similar to that found in the smaller channel-billed toucans.

Pipra aureola species group (Figure 9): These small manakins inhabit forests near lowland rivers and are very common in many regions of Amazonia (Haffer, 1970). Males are mainly black, bright red and yellow; females are inconspicuous green and very similar to one another. $P$. filicauda is slightly larger than the other species; its tail feathers are elongated and their shafts project as long wire-like filaments beyond the tail. This species inhabits most of upper Amazonia (north to the coast of Venezuela), whereas $P$. aureola is found in the floodplain forests of the lower Amazon and Madeira Rivers as well as along the coastal lowlands of the Guianas. P. fasciicauda occupies southern Amazonia and extended its range into northeastern and central Brazil. Where these Pipra species are in contact they replace each other geographically without (or very rarely) hybridizing. P. filicauda/P. fasciicauda meet along the Rios Huallaga, Ucayali, Juruá and Purus; $P$. aureola/P. fasciicauda meet along the Rios Madeira, Tapajós, Xingu and Tocantins their contact zone crossing these rivers at right angles.

The color patterns of the plumage indicate that $P$. aureola and $P$. fasciicauda are more closely related to each other than either of them is to P. filicauda. This indicates an earlier separation of ancestral populations in upper and lower Amazonia followed by later differentiation of the species to the north and south of the lower Amazon River (similar to the sequence of events in the Ramphastos toucans and probably also in the Pionopsitta parrots).

Pipra serena species group (Figure 10): This group of small forest manakins comprises several sharply differentiated geographical representatives that, in many areas, are among the most common forest birds (Haffer, 1970). The males of serena and coronata north of the Amazon River (and west of the Andes) are mainly black, those of the southern Amazonian forms extensively green with a yellow belly; the cap of the males is blue and white, respectively. The females are green and very similar. P. serena inhabits the lowlands to the north of the lower Amazon and the hilly interior of the Guianas. In southern Venezuela, $P$. (serena) suavissima is found in montane forests above $500 \mathrm{~m}$ a.s.1., in some regions above lowland forests that are inhabited by the upper Amazonian $P$. coronata with a blue cap in males. This species crossed the upper Amazon River southward and 


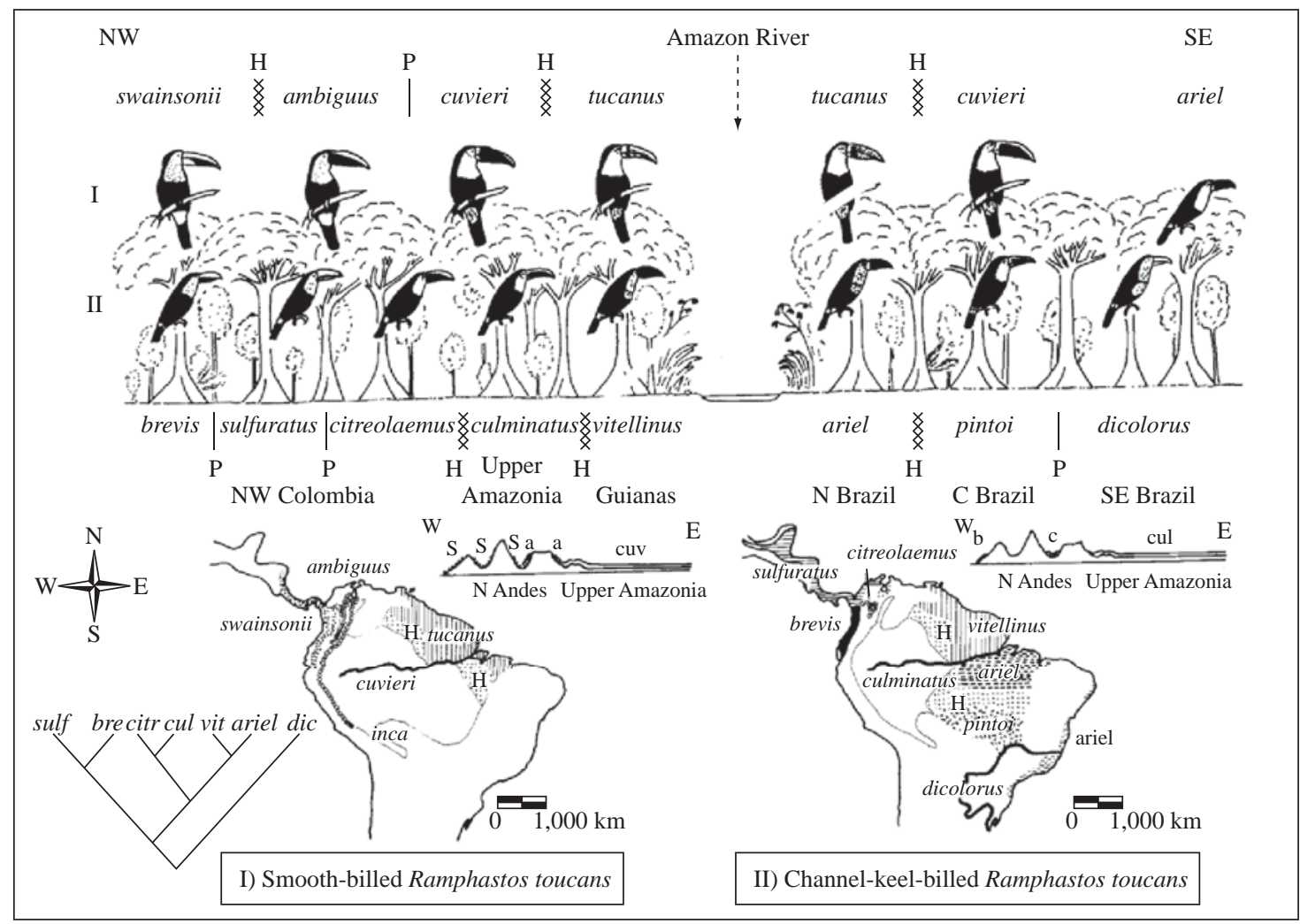

Figure 8. Ecological occurrence and distribution of the Ramphastos toucans. I) Smooth-billed "yelping" toucans (upper figures and left-hand map); and II) channel-keel-billed "grunting" toucans (lower figures and right-hand map). Color code for plumage: solid - black, blank - white, stippled - yellow, dashed - red or orange. Relations of taxa along contact zones: P - parapatry, H - hybridization (hybrid zone). Abbreviations along schematic profiles across northern Andes (next to maps): s - swainsonii, a - ambiguus, cuv - cuvieri, b - brevis, c - citreolaemus, cul - culminatus. Ramphastos toco, a large species with a keeled bill that inhabits mosaics of forest and savanna is not shown. Phylogenetic relations of taxa in the channel-keel-billed toucans are schematically illustrated in the lower left corner.

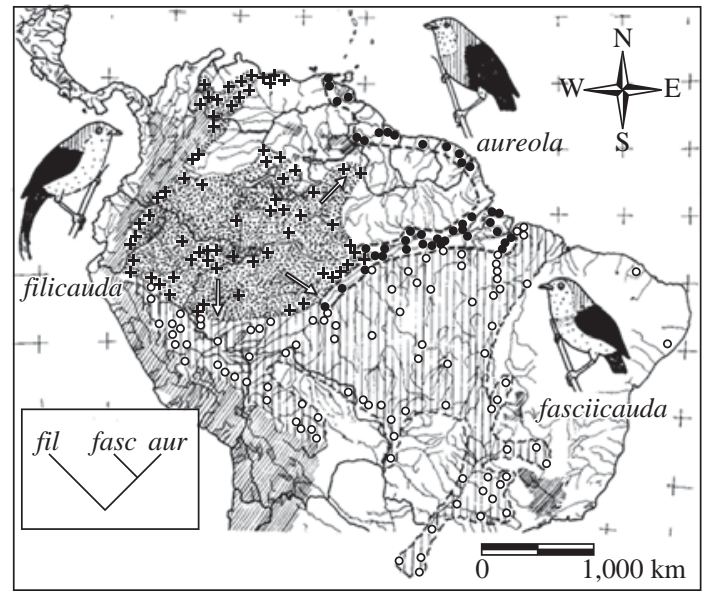

Figure 9. Distribution of the Pipra aureola species group (updated from Haffer, 1970). Symbols are locality records. Code for plumage color (adult male): Solid - black, hatched - red, stippled - yellow; iris is white. Phylogenetic relations of species are schematically illustrated in lower left corner. here hybridized extensively with the $P$. $c$. exquisita group of southwestern Amazonia.

Geographically representative species of the serena group in southeastern Amazonia are $P$. nattereri with a snow-white cap and rump in males and $P$. iris with a glistening opalescent cap. $P$. nattereri occurs between the lower Rio Madeira and Rio Tapajós and is widespread in southcentral Amazonia. It has crossed the narrow upper Rios Tapajós and Xingu in an eastward direction establishing contact with $P$. iris in this general region. The latter species inhabits the area east of the lower Rio Tapajós and most of the Rio Xingu Valley to the mouth of the Amazon River.

P. serena + suavissima of northeastern Amazonia and the Guianas together form the sister taxon of all other Amazonian species (Prum 1988). The male plumage color of the exquisita group in southwestern Amazonia with a blue cap (like coronata) and a green body with yellow belly (like nattereri-iris) is somewhat intermediate between coronata and the southeast Amazonian species. 


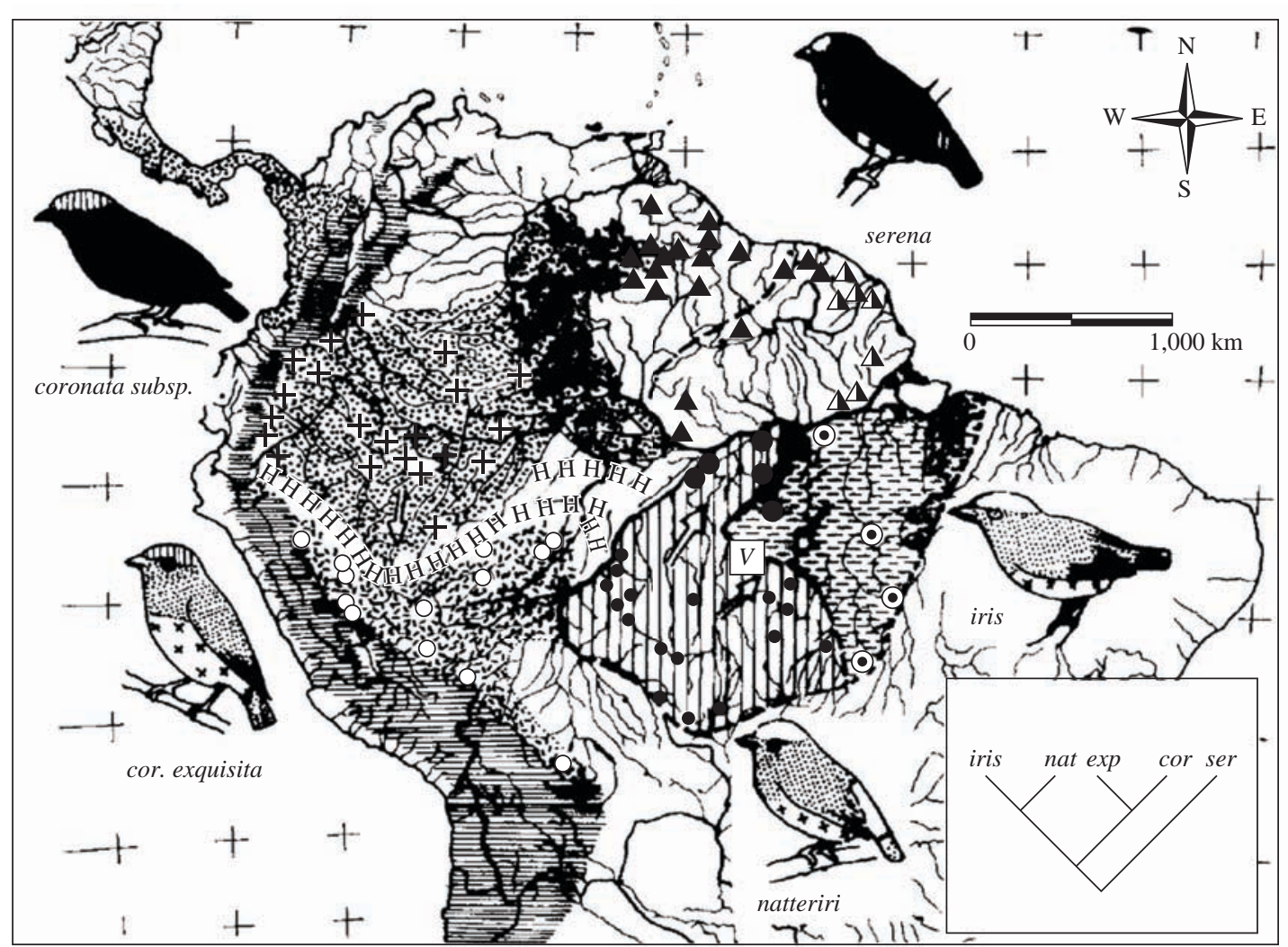

Figure 10. Distribution of the Pipra serena species group (updated from Haffer 1970). Locality records (symbols) are indicated for Amazonian forms only: Half-solid triangles - P. (s.) serena, solid triangles - P. (s.) suavissima; HHH - hybrid zone; $\mathrm{v}$ - type locality of $P$. vilasboasi“ (male with yellow cap), probably hybrids between $P$. nattereri and $P$. iris. Code for plumage color (adult male): Solid - black, blank - white, hatched - blue, heavy stipples - dark green, light stipples - green, crosses - yellow. The cap in P. iris is whitish opalescent. The phylogenetic relations among species are schematically illustrated at lower right corner (after Prum 1988).

The distribution maps of the Amazonian forest birds discussed above illustrate the following general aspects (Haffer, 1974; 1987b; 1992; 1997):

- mosaic distribution patterns of representative species that replace one another geographically with or without hybridization along their zones of contact characterize six areas of endemism in Amazonia (Figure 11);

- broad river courses separate the ranges of several species in central Amazonia;

- in northern and southern Amazonia, many representatives replace each other in terra firme forests along contact zones that are unrelated to the location of river courses which, in some cases, are crossed at right angles (Figure 12);

- these contact zones are probably zones of secondary contact implying large-scale separation of the respective bird populations during one or more periods during the geological past;

- the phylogenetic relations of the members of several species groups indicate that an earlier eastwest separation of upper and lower Amazonian ancestral forms preceded the later differentiation of species to the north and south of the lower Amazon River;

- the events of separation (vicariance) permitting speciation of the isolated populations were either due to paleogeographical changes in the distribution of land and sea or due to climaticvegetational fluctuations; the latter interpretation appears more likely in view of the paleoecological data discussed above.

\section{Discussion}

The different historical models proposed by various authors to explain the origin of species in Amazonia emphasize the biogeographic effect of tectonic movements and mountain building, the barrier effect of rivers, the changing composition and distribution of animal and plant communities due to climatic-vegetational fluctuations during the Cenozoic, the effect of environmental gradients, or a combination of these factors, that resulted in the geographical isolation and speciation of animal 


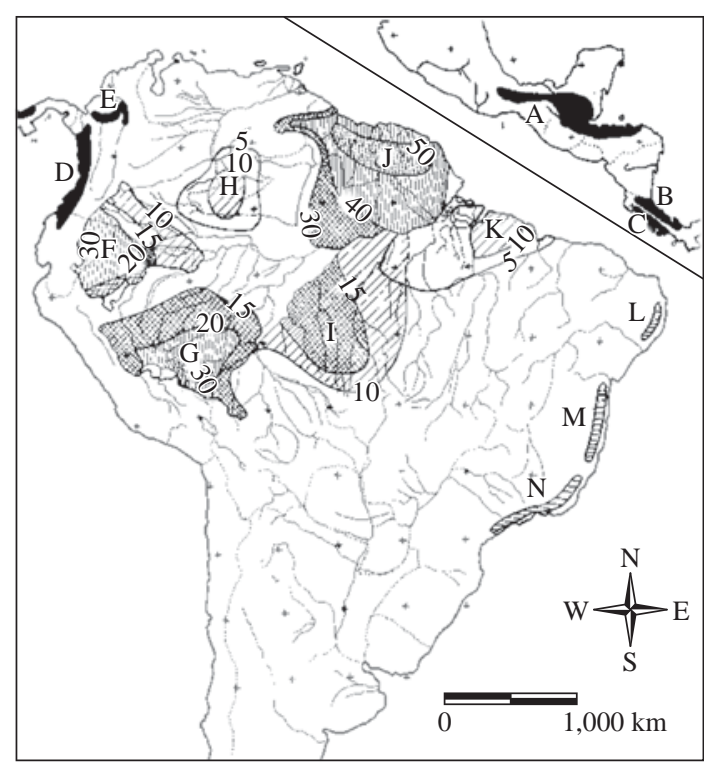

Figure 11. Areas of species endemism in the Neotropical lowland avifauna. Trans-Andean areas (solid): A - Guatemala (7 spp.), B - Caribbean Costa Rica (14 spp.), C - Pacific Costa Rica (12 spp.), D - Choco 32 spp.), E - Nechí (14 spp.). East Brazilian areas (hatched): L - Recife, M, $\mathrm{N}$ - Serra do Mar. Amazonian areas of endemism (with numbers of endemic species shown by shading and simplified by omitting some displaced extensions across major rivers): F - Napo, G - Inambari, H - Imerí, I - Rondonia, J - Guianas, K Belém (Haffer, 1987b).

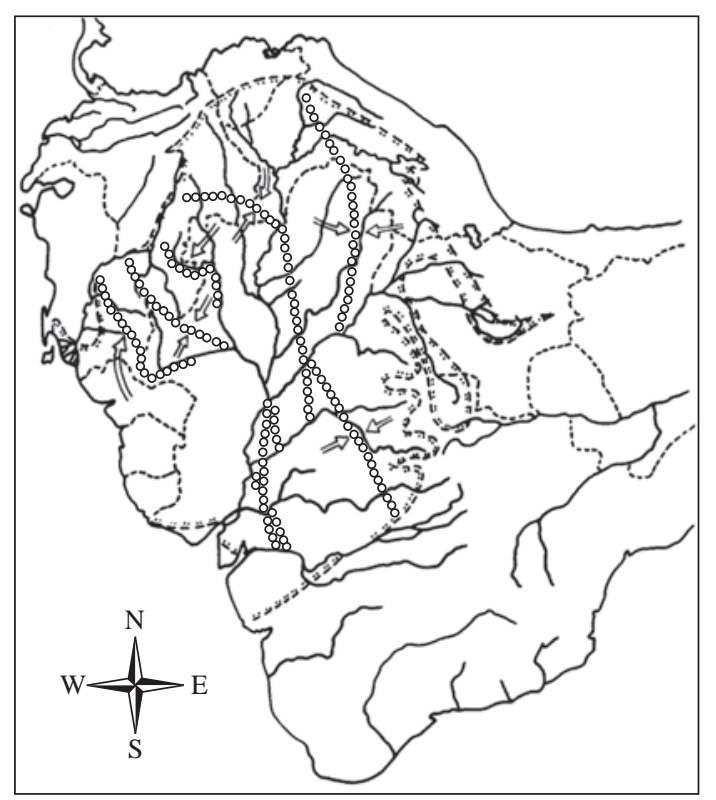

Figure 12. Location of selected contact zones between subspecies and species of birds in Amazonia. These zones of biogeographic discontinuity and geographical replacement are more or less independent of broad river courses. Open arrows symbolize advance of populations in contact today. Stippled line follows border of Amazonian-Guianan forest region. populations. Only the Gradient hypothesis is based on the model of parapatric speciation; all other hypotheses are based on the generally accepted theory of geographic (allopatric) speciation. Each of the models of allopatric speciation is probably relevant to a different degree for the speciation process in different faunal groups or during different geological periods.

Most biogeographers probably agree that the paleogeographic changes in the distribution of land and sea, as well as the uplift of the Andes, tepui mountains and other ranges, influenced the early evolution of the faunas during the Tertiary (of ca. 60 million years duration). However, the origin of many or most extant species and of their distribution patterns probably cannot be understood solely on the basis of such geological processes. Simultaneous ecological vicariance events through global climatic-vegetational fluctuations due to Milankovitch cycles of the Tertiary - Quaternary leading to the repeated separation of ecologically more or less stable "refugia" within or near areas of complex surface relief (Andes and peripheral areas of Amazonia) over many millions of years probably explain the origin of most species and species groups as we see them in the Neotropical Region today. The rainshadow effect during more localized processes of mountain building or block faulting probably also led to the formation of refugia or barrier zones in some regions, thus contributing to the faunal differentiation.

Fjeldsa (1994) presented a similar analysis emphasizing the indirect significance of the geomorphological processes of mountain building and the direct effect of paleoclimatic fluctuations. Speciation in the Andes took place in populations which were widely separated in ecologically more or less stable mountainous refugia. The pattern under present-day (humid) climatic conditions, with long linear distributions along the Amazonian (eastern) slope of the Andes and dense altitudinal replacements of closely related species, is a secondary state (Fjeldsa, 1992; 1994: 219). In other words, the geomorphological processes alone cannot explain the separation of populations and the speciation process in lowland and montane faunas of the tropics that directly depend on ecological vicariance due to climatic-vegetational changes. General discussions of area-relationships in the Neotropical lowlands based on the distributions of primates and passerine birds and their historical interpretations have been published by Silva and Oren (1996) and Bates et al. (1998), respectively.

A hierarchy of timeless environmental disturbance cycles ("Time's cycle") characterize the nature of Amazonia (Haffer 1993), from short-term treefall cycles and fluvial cycles to long-term climatic and paleoclimatic cycles (Figure 13). The latter cycles, in conjunction with the directional processes of mountain building, paleogeographical changes and erosion responsible for the development of pronounced surface relief in peripheral regions of Amazonia, permit an understanding of the multiplication of species and the origin of Amazonian 


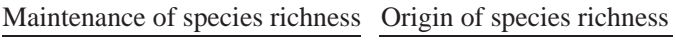
(Habitat heterogeneity) (Speciation and divergence)

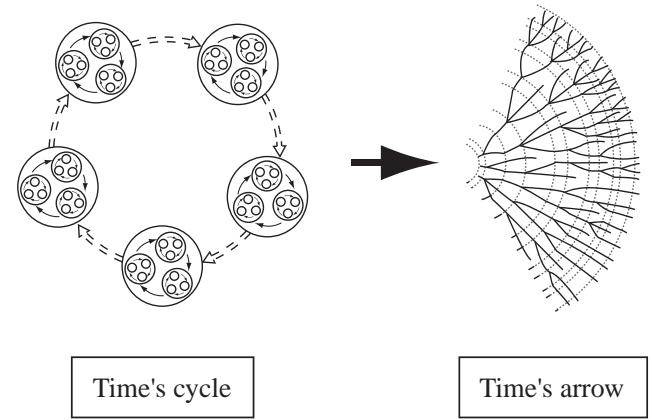

Figure 13. Time's cycle and Time's arrow in the history of Amazonia. Schematic representation. Left - Hierarchic disturbance cycles from treefall cycles (first order) and fluvial cycles (second order) to climatic and paleoclimatic cycles (third order) illustrate Time's cycle. These disturbance cycles, through generating habitat heterogeneity, contribute to the maintenance of high tropical species richness. Right - Time's arrow of genealogy along contingent evolutionary pathways. New species lineages are generated by paleoclimatic-vegetational cycles (symbolized by concentric stippled lines) which explain the origin of high tropical species richness. See text for further details (from Haffer, 1993).

species diversity (an example of "Time's arrow"). Most of the hypotheses reviewed above depend on conspicuous environmental instability over Amazonia as the driving mechanism of speciation, except for the basic River model and for the Gradient hypothesis (neither of which, however, appears to be applicable to a major portion of the Amazonian fauna). The evidence for climatic changes during the late Tertiary - Quaternary and their relations with evolutionary events has been discussed for many regions of the world, especially Africa, in a recent symposium volume (Vrba et al., 1995; see also Maley, 1996, and Lévêque, 1997), for the Malay Archipelago and New Guinea (Keast, 1996) and for the wet tropical regions of northseastern Australia (Joseph et al., 1995, Williams and Pearson, 1997; Schneider et al., 1998). Area cladograms of several African forests constructed using lists of endemic taxa of trees, butterflies, birds and primates were robust and statistically well-supported (Goldberg and Ruvolo 1997). These authors therefore concluded: "to the extent that PAE [parsimony analysis of endemicity] and ecological grouping accurately reconstruct history, the forests analysed appear to be related by a unique, discernible history which is broadly concordant with the predictions of Pleistocene refuge theory" (p. 317).

I repeat that some of the hypotheses proposed for an explanation of speciation in the tropics of the world and Amazonia in particular are highly relevant because they refer to recurrent geological events of barrier formation over the entire Cenozoic (island model and refuge model), whereas others are less relevant because they refer to specific (unique) events (e.g. the origin of the Amazonian river system) or to the most recent portion of the geological history (Pleistocene) after most species had originated (disturbance-vicariance theory).

Geological studies worldwide have established the fact that astronomical Milankovitch cycles causing global climatic-vegetational fluctuations influenced the continuously changing distribution of forest and nonforest vegetation on earth not only during the Ice Ages of the last 2 million years (Quaternary) but also during the entire Tertiary and before. These cycles caused sealevel oscillations, rhythmic facies changes of Mesozoic and Tertiary sedimentary strata, and climatic-vegetational shifts on the continents (Herbert and Fisher, 1986; Olsen,1986; Bartlein and Prentice, 1989; Berger et al., 1989; Bennett, 1990; 1997). These geologically rather short-term (high-frequency) oscillations were superimposed on a gradual cooling trend of the earth's climate since the beginning of the Cenozoic. Stronger cooling "events" occurred about 2.5 million years ago (Mya) and again 1.8 Mya. The latitudinal thermal gradient steepened during the course of the late Tertiary, when annual average temperatures increased in the tropics and the summer temperature decreased in high latitudes.

In recent years, many cladograms have been published for the species of families and genera of Neotropical animals usually with no discussions of the nature of the vicariance events which caused the numerous cladogenetic events underlying the speciation patterns depicted. It appears likely that frequent ecological vicariance due to climatic-vegetational fluctuations caused by Milankovitch cycles drove speciation in these groups of animals.

The cyclic formation and disappearance of forest and nonforest refugia due to the effect of global Milankovitch cycles during the Tertiary and Quaternary probably underlies, as a predictably reversible speciation mechanism, much of organic evolution on the continents (Terborgh, 1992). This statement is not intended to diminish in any way the general biogeographic significance of paleogeographic changes in the distribution of land and sea, as well as geomorphological changes in South America and other regions due to tectonic movements during the course of the geological history or of the far-reaching effect of continental rifting and subsequent continental drift. An understanding of the significance of these vicariance processes as well as of jump dispersal between mountain tops, islands in the ocean and between ecological "islands" on the continents is needed for a complete analysis of the zoogeographical history of the various groups of animals, in addition to that of the biogeographic effect of climatic-vegetational fluctuations.

Acknowledgements - I thank the coordinators Drs. David C. Oren and José Maria Cardoso da Silva for their invitation to participate in the symposium on "Biological and Cultural Diversity of Amazonia in a Changing World" held at the Museu Paraense Emilio Goeldi in Belém on the occasion of its $130^{\text {th }}$ anniversary, where I presented this contribution. I am 
also grateful to the European G 7 States for financial support. Jukka Salo and his group at the University of Turku (Finland) discussed with me several aspects of the ecology and history of Amazonia and provided recent literature references. M. Marroig, J. Patton and S. D. Webb sent me their manuscripts and reprints of their work.

\section{References}

AB'SÁBER, AN., 1982. The paleoclimate and paleoecology of Brazilian Amazonia. In Prance, GT. (Ed.). Biological Diversification in the Tropics. New York: Columbia University. p. 41-49.

ABSY, ML. 1979. A palynological study of Holocene sediments in the Amazon basin. Amsterdam: Academisch proefschrift.

ABSY, ML., CLEEF, A., FOURNIER, M., MARTIN, L., SERVANT, M., SIFFEDINE, A., FERREIRA da SILVA, M., SOUBIES, F., SUGUIO, K., TURCQ, B. and VAN DER HAMMEN, T., 1991. Mise en évidence de quatre phases d'ouverture de la foret dense dans le sud-est de l'Amazonie au cours des 60000 dernières années. Première comparaison avec d'autres régions tropicales. C. R. Acad. Sci. Paris, vol. 312, sér. II, p. 673 - 678.

AIDE, TM. and RIVERA, E., 1998. Geographic patterns of genetic diversity in Poulsenia armata (Moraceae): implications for the theory of Pleistocene refugia and the importance of riparian forest. J. Biogeogr., vol. 25, p. 695-705.

AYRES, JMC. 1986. Uakaris and Amazonian ooded forest. Cambridge: University of Cambridge. [PhD. Thesis].

AYRES, JMC. and CLUTTON-BROCK, TH., 1992. River boundaries and species range size in Amazonian primates. Amer. Natural., vol. 140, p. 531-537.

BARTLEIN, PJ. and PRENTICE, IC., 1989. Orbital variations, climate and paleoecology. Trends Ecol. Evol., vol. 4, p. 195-199.

BATES, HW., 1863. The naturalist on the river Amazons. London; Murray.

BATES, JM., HACKETT, SJ. and CRACRAFT, J., 1998. Arearelationships in the Neotropical lowlands: an hypothesis based on raw distributions of passerine birds. J. Biogeogr., vol. 25, p. $783-793$

BENNETT, KD., 1990. Milankovitch cycles and their effects on species in ecological and evolutionary time. Paleobiology, vol. 16, p. 11-21.

-, 1997. Evolution and Ecology. The Pace of Life. Cambridge: Cambridge University.

BERGER, A., LOUTRE, MF. and DEHANT, V., 1989. PreQuaternary Milankovitch frequencies. Nature, vol. 342, 133 p.

BETTENCOURT, JS., MUZZOLON, R., PAYOLLA, BL., DALL'IGNA, LG. and PINHO, OG., 1988. Depósitos estaníferos secundários de região central de Rondônia. In Principais Depósitos Minerais do Brasil. vol. 3. Brasília.

BIBUS, E., 1983. Die klimamorphologische Bedeutung von stone-lines und Decksedimenten in mehrgliedrigen Bodenprofilen Brasiliens. Zeitschr. Geomorph. N.F., vol. 48, suppl, p. 79-98.
BIGARELLA, JJ. and FERREIRA, AMM., 1985. Amazonian geology and the Pleistocene and the Cenozoic environments and paleoclimates. In PRANCE, GT. and LOVEJOY, TE. (Eds.). Amazonia. Key Environments. Oxford: Pergamon, p. 49-71.

BROWER, AVZ., 1996. Parallel race formation and the evolution of mimicry in Heliconius butterflies: a phylogenetic hypothesis from mitochondrial DNA sequences. Evolution, vol. 50, p. 195-221.

BROWN Jr., KS., SHEPPARD, PM. and TURNER, JRG., 1974. Quaternary refugia in tropical America: evidence from race formation in Heliconius butterflies. Proc. R. Soc. Lond. B., vol. 187, p. 369-378.

BURNHAM, RJ. and GRAHAM, A., 1999. The history of neotropical vegetation: new developments and status. Ann. Missouri Bot. Gdn., vol. 86, p. 546-589.

BUSH, MB., 1994. Amazonian speciation: a necessarily complex model. J. Biogeogr., vol. 21, p. 5-17.

CAMPBELL Jr., KE., 1990. The geologic basis of biogeographic patterns in Amazonia. In PETERS, G. and HUTTERER, R. (Eds.). Vertebrates in the Tropics. Bonn: Alexander Koenig Zoological Research Institute. p. 33-43.

CAMPBELL, Jr., KE., HEIZLER, M., FRAILEY, CD., ROMERO-PITTMAN, L. and ROTHERO, DR., 2001. Upper Cenozoic chronostratigraphy of the southwestern Amazon Basin. Geology, vol. 29, p. 595-598.

CAPPARELLA, A., 1988. Genetic variation in Neotropical birds: implications for the speciation process. Congress International Ornithology, 19. Acta, vol. 2, p. 1658-1664.

-, 1991. Neotropical avian diversity and riverine barriers. Congress International Ornithology, 20. Acta, vol. 1, p. 307-316.

CAPUTO, MV., 1991. Solimoes megashear: Intraplate tectonics in northwestern Brazil. Geology, vol. 19, p. 246-249.

CLAPPERTON, CM., 1993a. Quaternary geology and geomorphology of South America. Amsterdam: Elsevier.

-, 1993b. Nature of environmental changes in South America at the last glacial maximum. Palaeogeogr., Palaeoclimat., Palaeoecol., vol. 101, p. 189-208.

COLINVAUX, P., 1993. Pleistocene biogeography and diversity in tropical forests of South America. In: GOLDBLATT, P. (Ed.). Biological Relationships between Africa and South America. New Haven: Yale University. p. 473-499.

-, 1996. Quaternary environmental history and forest diversity in the Neotropics. In JACKSON, JBC., BUDD, AF. and COATES, A. (Eds.). Evolution and Environment in Tropical America. Chicago: University Press, p. 359-405.

-, 1998. A new vicariance model for Amazonian endemics. Global Ecol. Biogeogr. Letters, vol. 7, p. 95-97.

COLINVAUX, P., OLIVEIRA, PE., MORENO, JE., MILLER, MC. and BUSH, MB., 1996. A long pollen record from lowland Amazonia: Forest and cooling in glacial times. Science, vol. 274, p. 85-88.

COLINVAUX, PA., OLIVEIRA, PE. and BUSH. MB., 2000 Amazonian and neotropical plant communities on glacial time-scales: The failure of the aridity and refuge hypotheses. Quaternary Sci. Rev., vol. 19, p. 141-169. 
COWLING, SA., MASLIN, MA. and SYKES, MT., 2001. Paleovegetation simulations of lowland Amazonia and implications for neotropical allopatry and speciation. Quaternary Res., vol. 55, p. 140-149.

CRACRAFT, J. and PRUM, RO., 1988. Patterns and processes of diversification: Speciation and historical congruence in some Neotropical birds. Evolution, vol. 42, p. 603-620.

CROIZAT, L., 1976. Biogeografía analítica y sintética ("Panbiogeografía") de las Américas. v. 15., t.1-2. Caracas: Bibliotéca de la Academia de Ciencias Físicas, Matemáticas y Naturales.

DUELlMAN, WE., (Ed.), 1979. The South American herpetofauna: Its origin, evolution, and dispersal. v. 7. Kansas: Museum of Natural History/University of Kansas.

EDEN, MJ., McGREGOR, DFM. and MORELO, JA., 1982. Geomorphology of the middle Caquetá basin of eastern Colombia. Zeitschr. Geomorph. N.F., vol. 26, p. 343-364.

EMMERICH, KH., 1988. Relief, BödenundVegetationinZentralund Nordwest-Brasilien unter besonderer Berücksichtigung der Känozoischen Landschaftsentwicklung. Frankfurter Geowiss. Arbeiten, 218 p. ( Ser. D Phys. Geogr., 8)

EMSLEY, MG., 1965. Speciation in Heliconius (Lep., Nymphalidae): Morphology and geographic distribution. Zoologica (N.Y.) vol. 50, p. 191-254.

ENDLER, J., 1982. Pleistocene forest refuges: fact or fancy? In PRANCE, GT. (Ed.). Biological Diversification in the Tropics. New York: Columbia University Press, p. 179-200.

FJELDSA, J., 1992. Biogeographic patterns and evolution of the avifauna of relict high-altitude woodlands of the Andes. Steenstrupia, vol. 18, p. 9-62.

-. 1994. Geographical patterns for relict and young species of birds in Africa and South America and implications for conservation priorities. Biodiversity Conserv., vol. 3, p. 207-226.

FJELDSA, J.,LAMBIN,E. and MERTENS, B., 1999. Correlation between endemism and local ecoclimatic stability documented by comparing Andean bird distributions and remotely sensed land surface data. Ecography, vol. 22, p. 63-78.

FRAILEY, CD., LAVINA, EL., RANCY, A. and PEREIRA de SOUZA, J., 1988. A proposed Pleistocene/Holocene lake in the Amazon Basin and its significance to Amazonian geology and biogeography. Acta Amazon., vol. 18, p. 119-143.

FREITAS, HA., PESSENDA, LCR., ARAVENA, R., GOUVEIA, SEM., RIBEIRO, AS. and BOULET, R., 2001. Late Quaternary vegetation dynamics in the southern Amazon basin inferred from Carbon isotopes in soil organic matter. Quaternary Rese, vol. 55, p. 39-46.

FUTUYAMA, DJ. and SHAPIRO, LH., 1995. Hybrid zones. Evolution, vol. 49, p. 222-226.

GARNER, HF., 1974. The origin of landscapes. London: Oxford University Press.

-, 1975. Rain forests, deserts and evolution. An. Acad. Brasil. Cienc., vol. 47, supl, p. 127-133.

GASCON, C., LONGHEED, SC. and BOGART, JP., 1998. Patterns of genetic population differentiation in four species of Amazonian frogs: A test of the Riverine barrier hypothesis. Biotropica, vol. 30, p. 104-119.
GIBBONS, A., 1996. On the many origins of species. Special news report. Science, vol. 273, p. 1496-1499.

GOLDBERG, TL. and RUVOLO, M., 1997. Molecular phylogenetics and historical biogeography of east African chimpanzees. Biol. J. Linnean. Soc., vol. 61, p. 301-324.

GOTTSBERGER, G. and MORAWETZ, W. 1986. Floristic, structural and phytogeographical analysis of the savannas of Humaitá (Amazonas). Flora, vol. 178, p. 41-71.

HABERLE, SG. and MASLIN, MA. 1999. Late Quaternary vegetation and climate change in the Amazon basin based on a 50,000 year pollen record from the Amazon fan, ODP site 932. Quaternary Rese., vol. 51, p. 27-38.

HAFFER, J. 1969. Speciation in Amazonian forest birds. Science, vol. 165, p. 131-137.

-, 1970. Art-Entstehung bei einigen Waldvögeln Amazoniens. $J$. Ornithol., vol. 111, p. 285-331.

-, 1974. Avian speciation in tropical South America. Publ. Nuttall. Ornith. Club, vol. 14, p. 1-390.

-, 1978. Distribution of Amazon forest birds. Bonner Zool. Beitr., vol. 29, p. 38-78

-, 1979. Quaternary biogeography of tropical lowland South America. In DUELLMAN, WE. (Ed.). The South American herpetofauna: Its origin, evolution, and dispersal. Kansas: University of Kansas/Museum of Natural History, p. 107-140. [Monograph, 7].

-, 1981. Aspects of Neotropical bird speciation during the Cenozoic. In NELSON, G. and ROSEN, DE. (Eds.). Vicariance biogeography. New York: Columbia University Press, p. 371-394

-, 1982. General aspects of the refuge theory. In PRANCE, GT. (Ed.). Biological diversification in the tropics. New York: Columbia University. p. 6-24.

-, 1987a. Quaternary history of tropical America. In WHITMORE, TC. and PRANCE, GT. (Eds.). Biogeography and Quaternary history in tropical America. Oxford: Clarendon and Oxford University Press. p. 1-18.

-, 1987b. Biogeography of Neotropical birds. In WHITMORE, TC. and PRANCE, GT. (Eds.). Biogeography and Quaternary history in tropical America. Oxford: Clarendon and Oxford University Press. p. 105-150.

-, 1990. Geoscientific aspects of allopatric speciation. In PETERS, G. and HUTTERER, R. (Eds.). Vertebrates in the tropics. Bonn: Alexander Koenig Research Institute. p. 45-60.

-, 1992. On the "river effect" in some forest birds of southern Amazonia. Bol. Mus. Para. Emilio Goeldi, sér. Zool., vol. 8, p. 217-245.

-, 1993. Time's cycle and time's arrow in the history of Amazonia. Biogeographica, vol. 69, p. 15-45.

-, 1997. Contact zones between birds of southern Amazonia. Ornithol. Monogr., vol. 48, p. 281-305.

HELLMAYR, CE., 1910. The birds of the Rio Madeira. Novit. Zoolog., vol. 17, p. 257-428.

-, 1912. Zoologische Ergebnisse einer Reise in das Mündungsgebiet des Amazonas (L. Müller). II. Vögel. München: Bayerische Akademie der Wissenschaften, vol. 26, p. 1-142. 
HERBERT, TD. and FISCHER, AG., 1986. Milankovitch climatic origin of mid-Cretaceous black shale rhythms in central Italy. Nature, vol. 321, p. 739-743.

HERSHKOVITZ, P., 1977. Living New World monkeys (Platyrrhini). Chicago: University of Chicago Press.

HOOGHIEMSTRA, H. and VAN DER HAMMEN, T., 1998. Neogene and Quaternary development of the neotropical rain forest: the forest refugia hypothesis, and a literature overview. Earth-Sci.Rev., vol. 44, p. 147-183.

HOORN, C., GUERRERO, J., SARMIENTO, GA. and LORENTE, MA., 1995. Andean tectonics as a cause for changing drainage patterns in Miocene northern South America. Am. Geol., vol. 23, p. 237-240.

HUBER, JH., 1998. Comparison of Old World and New World tropical cyprinodents. Paris: Museum National d'Histoire Naturelle, Laboratoire d'Ichthyologie Général.

IRION, G., 1984a. Sedimentation and sediments of Amazonian rivers and evolution of the Amazonian landscape since Pliocene times. In SIOLI, H. (Ed.). The Amazon. Limnology and landscape ecology of a mighty tropical river and its basin. Dordrecht: Junk Publishers. p. 201-214.

-, 1984b. Clay minerals of Amazonian soils. In SIOLI, H. (Ed.). The Amazon. Limnology and landscape ecology of a mighty tropical river and its basin. Dordrecht: Junk Publishers, p. $537-561$

IRIONDO, M. and LATRUBESSE, EM., 1994. A probable scenario for a dry climate in central Amazonia during the late Quaternary. Quaternary Internat., vol. 21, p. 121-128.

IRIONDO, M. and SUGUIO, K., 1981. Neotectonics of the Amazon floodplain. Bull. INQUA Neotectonics Commisission, Stockholm, vol. 4, p. 72-78.

JACKSON, JBC., BUDD, AF. and COATES, AG., (Eds.). Evolution and Environment in Tropical America. Chicago: University of Chicago.

JEGU, M. and SANTOS, GM., 1993. Quaternary variation of sea level and present aquatic refuges in central and eastern Amazonia. In Abstracts the International Symposium on the Quaternary of Amazonia, Manaus.

JOSEPH, L., MORITZ, C. and HUGALL, A., 1995. Molecular support for vicariance as a source of diversity in rainforest. Proc. R. Soc. Lond. B, vol. 260, p. 177-182.

KATZER, F., 1903. Grundzüge der Geologie des unteren Amazonasgebietes. Leipzig: Weg.

KEAST, A., 1996. Avian geography: New Guinea to the eastern Pacific. In KEAST, A. and MILLER, SE. (Eds.). The origin and evolution of Pacific island biotas, New Guinea to eastern Polynesia: Patterns and processes. Amsterdam: Academic Publishing. p. 373-398.

KLAMMER, G., 1984. The relief of the extra-Andean Amazon basin. In SIOLI, H. (Ed.). The Amazon. Limnology and landscape ecology of a mighty tropical river and its basin. Dordrecht: Junk Publishers. p. 47-83.

KRONBERG, BI. and BENCHIMOL, RE., 1990. Climate changes reflected in geochemistry and stratigraphy of Acre basin sediments (western Amazonia). Quaternary South Am. Antarctic Peninsula, vol. 8, p. 191-199.
KRONBERG, BI., BENCHIMOL, RE. and BIRD, MI., 1991. Geochemistry of Acre Subbasin sediments: window on Ice-Age Amazonia. Interciencia, vol. 16, p. 138-141.

LATRUBESSE, EM. and RANCY, A., 1998. The late Quaternary of the Juruá River, southwestern Amazonia: geology and vertebrate paleontology. Quaternary South Am. Antarctic Peninsula, vol. 11, p. 27-46.

LAUER, W., 1988. Zum Wandel der Vegetationszonierung in den lateinamerikanischen Tropen seit dem Höhepunkt der letzten Eiszeit. Jahrbuch Geograph. Gesellsch., Hannover, p. 1-45.

LEDRU, MP., BERTAUX, J., SIFEDDINE, A. and SUGUIO, K., 1998. Absence of Last Glacial Maximum records in lowland tropical forests. Quaternary Rese., vol. 49, p. 233-237.

LÉvÊQUE, C., 1997. Biodiversity dynamics and conservation. The freshwater fish of tropical Africa. Cambridge: Cambridge University.

LYNCH, JD., 1988. Refugia. In MYERS, AA. and GILLER, PS. (Eds.). Analytical biogeography. London: Chapman and Hall. p. 311-342.

MALEY, J., 1996. The African rainforest - main characteristics of changes in vegetation and climate from the Upper Cretaceous to the Quaternary. Proc. R. Soc. Edinb., vol. 104b, p. 31-73.

MALLET, J., 1993. Speciation, raciation, and color pattern evolution in Heliconius butterflies: Evidence from hybrid zones. In HARRISON, RG. (Ed.). Hybrid zones and the evolutionary process. Oxford: Oxford University. p. 226-260.

MARES, MA. and GENOWAYS, HH.,(Eds.), 1982. Mammalian biology in South America. Pittsburgh: Pymatuning Labororatory of Ecology. (Special Publication, 6).

MARROIG, G. and CERQUEIRA, R., 1997. Plio-Pleistocene South American history and the Amazon Lagoon hypothesis: a piece in the puzzle of Amazonian diversification. J. Comp. Biol., vol. 2, no. 2, p. 103-119.

MASLIN, MA. and BURNS, SJ., 2000. Reconstruction of the Amazon Basin effective moisture availability over the past 14,000 years. Science, vol. 290, p. 2285-2287.

MAYR, E., 1942. Systematics and the origin of species from the viewpoint of a zoologist. New York: Columbia University.

-, 1963. Animal species and evolution. Cambridge: Harvard University.

MAYR, E. and O'HARA, RJ., 1986. The biogeographic evidence supporting the Pleistocene forest refuge hypothesis. Evolution, vol. 40, p. 55-67.

MEAVE, J. and KELLMAN, M. 1994. Maintenance of rainforest diversity in riparian forests of tropical savannas: implications for species conservation during PLeistocene drought. J. Biogeogr., vol. 21, p. 121-135.

MEAVE, J., KELLMAN, M., MACDOUGALL, A. and ROSALES, J., 1991. Riparian habitats as tropical forest refugia. Global Ecol. Biogeogr. Letters, vol. 1, p. 69-76.

MERTES, LAK., DUNNE, T. and MARTINELLI, LA., 1996. Channel-floodplain geomorphology along the Solimões-Amazon River, Brazil. Geol. Soc. Am. Bull., vol. 108, p. 1089-1107. 
MORELL, V., 1996. Amazonian diversity: A river doesn't run through it. Special news report. Science, vol. 273, p. 1496-1497.

MORLEY, RJ., 2000. Origin and evolution of tropical rain forests. New York.

MOSMANN, R., FALKENHAIN, FUH., GONZALES, A. and NEPOMUCENO, FF., 1986. Oil and gas potential of the Amazon Paleozoic basins. In HALBOUTY, MT. (Ed.). Future petroleum provinces of the world. American Associoation Petrology Geology. p. 207-241 (Memoir, 40).

MÜLlER, P., 1973. The Dispersal Centres of Terrestrial Vertebrates in the Neotropical Realm. The Hague. 244 p.

MÜLLER, J., IRION, G., MELLO, JN. and JUNK, W., 1995. Hydrological changes of the Amazon during the last glacialinterglacial cycle in central Amazonia. Naturwissenschaften, vol. 82, p. 232-235.

NORES, M., 1999. An alternative hypothesis for the origin of Amazonian bird diversity. J. Biogeogr., vol. 26, p. 475-485.

NUTTALL, CP., 1990. A review of the Tertiary non-marine molluscan faunas of the Pebasian and other inland basins of north-western South America. Bull. Brit. Mus. Nat. Hist. Geol., vol. 45 , p. 165-371.

OLSEN, PE., 1986. A 40-million-year lake record of Early Mesozoic orbital climatic forcing. Science, vol. 234, p. $842-848$.

PATTON, JL. and SMITH, MF., 1992. MtDNA phylogeny of Andean mice: a test of diversification across ecological gradients. Evolution, vol. 46, p. 174-183.

PATTON, JL., SILVA, MN. and MALCOLM, JR., 1994. Gene genealogy and differentiation among arboreal spiny rats (Rodentia: Echimyidae) of the Amazon basin: A test of the Riverine barrier hypothesis. Evolution, vol. 48, p. 1314-1323.

-, 1997. Diversity, differentiation, and the historical biogeography of nonvolant small mammals of the Neotropical forests. In LAURANCE, WF. and BIERREGAARD Jr, RO. (Eds.). Tropical Forest Remnants: Ecology, Management and Conservation of Fragmented Communities. Chicago: University of Chicago. p. 455-465

PATTON, JL., SILVA, MN. and MALCOLM, JR., 2000. Mammals of the Rio Juruá and the evolutionary and ecological diversification of Amazonia. Bull. Am. Mus. Nat. Hist., vol. 244, p. $1-306$

PERES, CA., PATTON, JL. and SILVA, MN., 1996. Riverine barriers and gene flow in Amazonian Saddle-back Tamarins. Folia Primatol., vol. 67, p. 113-124.

PETRI, S. and FULFARO, VJ., 1983. Geología do Brasil. Sao Paulo: Universidae de Sao Paulo.

PRANCE, GT., 1973. Phytogeographic support for the theory of Pleistocene forest refuges in the Amazon basin, based on evidence from distribution patterns in Caryocaraceae, Chrysobalanacae, Dichapetalaceae and Lecythidaceae. Acta Amazon., vol. 3, p. 5-28.

-, 1982. Biological diversification in the tropics. New York: Columbia University.

-, 1996. Islands in Amazonia. Phil. Trans. R. Soc. Lond. B, vol. 351, p. $823-833$.
PRANCE, GT. and LOVEJOY, TE., (Eds.). 1985. Amazonia. Key environments. Oxford: Pergamon Press.

PROJETO RADAMBRASIL. 1976. Folha SC-19. Rio Branco, vol. 12.

-, 1977. Folha SB-19. Rio Juruá, vol. 15.

PRUM, RO., 1988. Historical relationships among avian forest areas of endemism in the Neotropics. Congress International Ornithology, 19. Acta, vol. 2, p. 2562-2572.

RÄSÄNEN, ME., SALO, JS., JUNGNER, H. and PITTMAN, LR., 1990. Evolution of the western Amazon lowland relief: impact of Andean foreland dynamics. Terra Nova, vol. 2, p. 320-332.

RÄSÄNEN, M., NELLER, R., SALO, J. and JUNGNER, H., 1992. Recent and ancient fluvial deposition systems in the Amazonian foreland basin, Peru. Geol. Mag., vol. 129, p. 293-306.

RÄSÄNEN, ME., LINNA, AM., SANTOS, JCR. and NEGRI, FR., 1995. Late Miocene tidal deposits in the Amazonian foreland basin. Science, vol. 269, p. 386-390.

RANCY, A., 1991. Pleistocene mammals and paleoecology of the western Amazon. Ann Arbor: University of Florida. [Ph.D. thesis].

-, 1993. A paleofauna da Amazonia indica áreas de pastagem com pouca cobertura vegetal. Ciência Hoje, vol. 16, no. 93, p. $48-51$.

RON, SR., 2000. Biogeographic area relationships of lowland Neotropical rainforest based on raw distributions of vertebrate groups. Biol. J. Linn. Soc., vol. 71, p. 379-402.

ROY, MS., SILVA, JMC., ARCTANDER, P., GARCIAMORENO, J. and FJELDSA, J., 1997. The speciation of South American and African birds in montane regions. In MINDELL, DP. (Ed.). Avian Molecular Evolution and Systematics. New York: Academic Press. p. 325-343.

SANTOS, JOS., NELSON, BW. and GIOVANNINI, CA., 1993. Corpos de areia sob leitos abandonados de grandes rios. Ciência Hoje, vol. 16, no. 93, p. 22-25.

SCHAEFER, C. and DALRYMPLE, J., 1995. Landscape evolution in Roraima, north Amazonia: planation, paleosols and paleoclimates. Z. Geomorph. N.F. vol. 39, p. 1-28.

SCHLIEWEN, UK., TAUTZ, D. and PÄÄBO, S., 1994. Sympatric speciation suggested by monophyly of crater lake cichlids. Nature, vol. 368, p. 629-632.

SCHNEIDER, CJ., CUNNINGHAM, M. and MORITZ, C., 1998. Comparative phylogeography and the history of endemic vertebrates in the Wet Tropics rainforests of Australia. Mol. Evol., vol. 7, p. 487-498.

SCHNEIDER, CJ., SMITH, TB., LARISON, B. and MORITZ, C., 1999. A test of alternative models of diversification in tropical rainforests: Ecological gradients vs. rainforest refugia. Proc. Natl. Acad. Sci. USA, vol. 96, p. 13869-13873.

SCHUBERT, C., 1988. Climatic changes during the last glacial maximum in northern South Americas and the Caribbean: A review. Interciência, vol. 13, p. 128-137.

SCHUBERT, C., FRITZ, P. and ARAVENA, R., 1994. Late Quaternary paleoenvironmental studies in the Gran Sabana 
(Venezuelan Guayana Shield). Quaternary Internat., vol. 21, p. 81-90.

SHACKLTON, NJ., BERGER, A. and PELTIER, WR., 1990. An alternative astronomical calibration of the lower Pleistocene time scale based on EDP Site 677. Trans. R. Soc. Edinburgh: Earth Sci., vol. 81, p. 251-261.

SICK, H., 1967. Rios e enchentes na Amazonia como obstáculo para a avifauna. Simpósio sobre a Biota Amazônica. Atas. Zoologia, vol. 5, p. 495-520.

SILVA, JMC. and OREN, DC., 1996. Application of parsimony analysis of endemicity in Amazonian biogeography: an example with primates. Biol. J. Linn. Soc., vol. 59, p. 427-437.

SILVA, M. and PATTON, JL., 1993. Amazonian phylogeography: mtDNA sequence variation in arboreal echimyid rodents (Caviomorpha). Mol. Phyl. Evol., vol. 2, p. 343-255.

SIMPSON, BB. and HAFFER, J., 1978. Speciation patterns in the Amazonian forest biota. Ann. Rev. Ecol. Syst., vol. 9, p. 497-518.

SNETHLAGE, E., 1913. Über die Verbreitung der Vogelarten in Unteramazonien. J. Ornithol., vol. 61, p. 469-539.

SOMBROEK, WG., 1966. Amazon soils. Wageningen: Centrum voor Landbouwpublikaties.

TERBORGH, J., 1992. Diversity and the tropical rain forest. New York: Freeman.

THOMAS, MF., 2000. Late Quaternary environmental changes and the alluvial record in humid tropical environments. Quaternary Intern., vol. 72, p. 23-36.

THOMPSON, LG., MOSLEY-THOMPSON, E., DAVIS, ME., LIN, PN., HENDERSON, KA., COLE-DAI, J., BOLZAN, JF. and LIU, Kb., 1995. Late glacial stage and Holocene tropical ice core records from Huascarán, Peru. Science, vol. 269, p. 46-50.

TREGENZA, T. and BUTLIN, RK., 1999. Speciation without isolation. Nature, vol. 400, p. 311-312.

TRICART, J., 1974. Existence de périodes sèches au Quaternaire en Amazonie et dans les régions voisines. Rev. Géomorph. Dyn., vol. 23, p. 145-158.

-, 1985. Evidence of Upper Pleistocene dry climates in northern South America. In DOUGLAS, I. and SPENCER, T. (Eds.). Environmental change and tropical geomorphology. Boston: Allen and Unwin. p. 197-217.

TUOMISTO, H., RUOKOLAINEN, K. and SALO, J., 1993. Lago Amazonas: Fact or fancy? Acta Amazon., vol. 33, p. 353-361.

TURNER, JRG. and MALLET, JLB., 1996. Did forest islands drive the diversity of warningly coloured butterflies ? Biotic drift and the shifting balance. Phil. Trans. R. Soc. Lond. B, vol. 351 , p. $835-845$.

VAN DER HAMMEN, T. and ABSY, ML., 1994. Amazonia during the last glacial. Palaeogeogr., Palaeoclimatol., Palaeoecol., vol. 109, p. 247-261.

VAN DER HAMMEN, T. and HOOGHIEMSTRA, H., 2000. Neogene and Quaternary history of vegetation, climate, and plant diversity in Amazonia. Quaternary Sci.Rev., vol. 19, p. $725-742$.
VANZOLINI, PE., 1970. Zoología sistemática, geografía e a origem das espécies. São Paulo: Instituto Geográfico de São Paulo. 56 p.

VANZOLINI, PE., 1973. Paleoclimates, relief, and species multiplication in equatorial forests. In MEGGERS, BJ., AYENSU, ES. and DUCKWORTH, WD. (Eds.). Tropical forest ecosystems in Africa and South America: A comparative review. Washington: Smithsonian Institution. p. 255-258.

VANZOLINI, PE., 1992. Paleoclimas e especiacao em animais da América do Sul tropical. São Paulo. Estud. Avancados, vol. 6, no. 15 , p. $41-65$.

VANZOLINI, PE. and WILLIAMS, EE., 1970. South American anoles: Geographic differentiation and evolution of the Anolis chrysolepis species group (Sauria, Iguanidae). Arq. Zoolog., vol. 19, p. 1-298.

VEIGA, ATC., 1991. Paleoenvironmental and archeological significance of alluvial placers of the Brazilian Amazon. In Proceedings the Symposium on Global Changes in South America during the Quaternary. São Paulo: USP. p. 213-222 (Publicação Especial, 8).

VEIGA, ATC. DARDENNE, MA. and SALOMÃO, EP., 1988. Geologia dos aluviões auríferos e estaníferos da Amazônia. In Anais do 35 Congresso Brasileiro de Geologia. Belém. vol. 1, p. $164-177$.

VRBA, ES., 1992. Mammals as a key to evolutionary theory. $J$. Mammal., vol. 73, p. 1-28.

-, 1993. Mammal evolution in the African Neogene and a new look at the Great American interchange. In GOLDBLATT, P. (Ed.). Biological relationships between Africa and South America. New Haven: Yale University. p. 393-432.

-, 1995. On the connections between paleoclimate and evolution. In VRBA, ES., DENTON, GH., ARTRIDGE, TC. and BURCKLE, LH. (Eds.). Paleoclimate and evolution, with emphasis on human origin. New Haven:Yale University. p. 24-45.

VRBA, ES., DENTON, GH.,PARTRIDGE, TC. and BURCKLE, LH., (Eds.), 1995. Paleoclimate and evolution, with emphasis on human origins. New Haven: Yale University Press.

WALLACE, AR., 1852. On the monkeys of the Amazon. London. Proc. Zool. Soc., vol. 1852, p. 107-110.

-, 1853. A narrative of travels on the Amazon and Rio Negro. London: Reeve.

WEBB, SD., 1991. Ecogeography and the Great American Interchange. Paleobiology, vol. 17, p. 266-280.

-, 1995. Biological implications of the Middle Miocene Amazon seaway. Science, vol. 269, p. 361-362.

WEBB, SD. and RANCY, A., 1996. Late Cenozoic evolution of the Neotropical mammal fauna. In JACKSON, JBC., BUDD, AF. and COATES, AG. (Eds.). Evolution and Environment in Tropical America. Chicago: Chicago University. p. 335-358.

WHITMORE, RT. and PRANCE, GT., (Eds.), 1987. Biogeography and Quaternary history in tropical America. Oxford: Clarendon Press. (Monograpf on Biogeography, 3).

WILLIAMS, SE. and PEARSON, RG., 1997. Historical rainforest contractions, localized extinctions and patterns of vertebrate endemism in the rainforests of Australia's wet tropics. Proc. R. Soc. Lond. B, vol. 264, p. 709-716.

WILLIS, KJ. and WHITTAKER, RJ., 2000. The refugial debate. Science, vol. 287, p. 1406-1407. 